FIU Law Review

Fall 2012

\title{
Police Powers for Sale: Red-Light Enforcement Sold to the Foreign Bidder
}

Andrea Franklin

Follow this and additional works at: https://ecollections.law.fiu.edu/lawreview

Part of the Other Law Commons

Online ISSN: 2643-7759

\section{Recommended Citation}

Andrea Franklin, Police Powers for Sale: Red-Light Enforcement Sold to the Foreign Bidder, 8 FIU L. Rev. 137 (2012).

DOI: https://dx.doi.org/10.25148/lawrev.8.1.13

This Article is brought to you for free and open access by eCollections. It has been accepted for inclusion in FIU Law Review by an authorized editor of eCollections. For more information, please contact lisdavis@fiu.edu. 


\title{
Police Powers for Sale: Red-Light Enforcement Sold to the Foreign Bidder
}

\author{
Andrea Franklin*
}

\section{INTRODUCTION}

Red-light cameras have been popping up all over major intersections and headlining news stories nationwide. Undoubtedly, public outcry over this relatively innovative technology may be rooted in the conspiracy theorist's Orwellian "Big Brother" notion that the government monitors the citizen and invades his personal freedoms; however, on a less-exaggerated notion, public outcry may be driven by the deep-seated belief that this new technology is inherently wrong.

Many violators who received citations have challenged the constitutionality of the whole red-light-camera program, but few, if any, have had any luck in the courtroom. ${ }^{1}$ Judges hearing appeals of violations have frequently disregarded statutory parameters and simply dismissed any disputed violations. ${ }^{2}$ Since the introduction of automated

This comment was authored by Andrea M. Franklin, a third-year law student at Florida International University College of Law. Special thanks to: Professor John Stack for encouraging me to continue researching after I thought the constitutionality of the red-light cameras was the end of the legal discussion on this topic; the FIU Law Review Editorial Board, Courtney Walter, Cristina Neuman, Jennifer Soberal, and Erin Auble, for their relentless dedication to furthering the development and academic success of FIU Law; and, finally, to my family and friends for putting up with me, even when I made it difficult to do so.

1 See, e.g., Akbar v. Daley, No. 09-cv-1289, 2009 WL 3055322 (N.D. Ill. 2009) (finding state did not violate plaintiff's right to equal protection merely because cameras were installed at some intersections); Williams v. Redflex Traffic Sys., Inc., No. 3:06-cv-400, 2008 WL 782540 (E.D. Tenn. 2008) (finding plaintiff's right to procedural due process was not violated by a $\$ 50$ civil penalty for red-light-camera violation); Idris v. City of Chicago, No. 06-C-6085, 2008 WL 182248 (N.D. Ill. 2008) (finding state's imposition of vicarious liability on car owners, but not on car dealerships or lessors, did not violate the Equal Protection Clause); Agomo v. Fenty, 916 A.2d 181 (D.C. 2007) (finding state's statutory presumption of liability did not impinge on car owner's right to due process).

2 See generally Jackelyn Barnard, Red Light Cameras Have Drivers Explaining Themselves in Courtht [sic], FIRST COAST NEwS (Jan. 6, 2012), http://www.firstcoastnews.com/news/ local/article/234758/3/Think-Youve-Heard-it-All-A-Visit-to-Red-Light-Camera-Court; Brooke Edwards, California Courts Throwing Out Red Light Camera Tickets, VICTORVILLE DAILY PRESS (Jan. 22, 2011), http://www.vvdailypress.com/news/throwing-25536-california-tickets.html; Jane Musgrave, About 50 People Have Red-Light Camera Tickets Dismissed in West Palm and Palm Springs, SUN SENTINEL (Jan. 18, 2011), http://articles.sun-sentinel.com/2011-01-18/news/fl-palm- 
traffic detection systems, also known as traffic infraction detectors, including red-light cameras, a flurry of issues have arisen surrounding this relatively undeveloped and unarticulated legal debate. ${ }^{3}$

The precedential case law is scarce and sparse around the entire nation. Some states have banned the use of such automated systems; others have implemented programs utilizing the systems. In almost every state where the systems have been implemented, petitioners have raised constitutional issues, albeit rather unsuccessfully, based on the Fourteenth Amendment's Due Process and Equal Protection Clauses, the Sixth Amendment's Confrontation Clause, Miranda rights and the Fifth Amendment's protection against self-incrimination, the Fourth Amendment protection against unreasonable search and seizure, and various privacy issues stemming from state law. Such claims rarely, if ever, prevail. Legal scholars and political decision-makers have only recently begun to focus on the impact of these systems, especially in terms of legality and public policy.

The U.S. Department of Transportation's Federal Highway Administration has published Red Light Camera Systems: Operational Guidelines, but these guidelines are not binding and are merely suggestive. ${ }^{4}$ Different states have exercised their police powers to enact legislation, which contain some uniformity with the federal guidelines but also contain particular regional specifications.

red-light-cameras-folo-20110118_1_red-light-camera-tickets-red-light-intersections-last-year; Associated Press, Judge Dismisses Nearly 300 Red-Light Camera Tickets in San Diego (Sept. 5, 2001), available at http://lubbockonline.com/stories/090501/upd_075-6389.shtml; 292 Red-Light Tickets Voided in Suit Over Automated Cameras, CHI. TRIB., Sept. 5, 2001, § News, at 12. But see Dan Tracy \& Scott Powers, Red-Light Camera Laws Enforced Erratically When It Comes to Right Turns, ORLANDO SENTINEL (May 14, 2011), http://articles.orlandosentinel.com/2011-0514/news/os-red-light-cameras-project-20110513_1_red-light-camera-tickets-motorists-appealyellow-lights.

3 See generally Robin Miller, J.D., Annotation, Automated Traffic Enforcement Systems, 26 A.L.R. 6TH 179 (2007).

4 U.S. Dep'T Transp., Fed. Highway Admin., Red Light CAMERA Systems: OPERATIONAL GUIDELINES, Jan. 2005, available at http://safety.fhwa.dot.gov/intersection/ redlight/cameras/fhwasa05002/fhwasa05002.pdf [hereinafter U.S. DEP'T TRANSP., OPERATIONAL GUIDELINES].

5 Compare ARK. CODE ANN. §§ 27-52-110, -111 (2005) (permitting red light cameras for specific reasons, such as school zones or railroad crossings); COLO. REV. STAT. ANN. § 42-4$110.5(2)(\mathrm{g})(2004)$ (permitting cameras within a school zone, residential neighborhood, or along a street bordering a municipal park); MD. CODE ANN., TRANSP. § 21-809 (2011) (permitting cameras within a school zone or highway in a residential district); NEV. REV. STAT. ANN. § 484.910 (2009) (permitting only handheld automated infraction detectors, such as radar detectors, or automated detectors installed within law enforcement vehicle or facility), with N.J. STAT. ANN. § 39:4-103.1 (2002) (prohibiting photo-radar enforcement); W. VA. CODE § 17C-6-7a (2007) (prohibiting "traffic law photo-monitoring device"); WIS. STAT. ANN. § 349.02(3) (2005) (prohibiting "photo radar speed detection"). 
Specifically, Florida's Mark Wandall Traffic Safety Act ${ }^{6}$ authorizes the use of automated traffic infraction detectors, but the Statute's delegation to local authorities is broad and vaguely permissive. Prior to the enactment of the Mark Wandall Act, in order to issue a traffic citation, a traffic enforcement officer was required to personally issue a citation for a violation that occurred in the presence of an officer; furthermore, the alleged violator was required to sign and accept the citation, constituting service and notice. ' Now, since the Act allows issuance of a citation without personal service and/or in the presence of a traffic enforcement officer, most local governments that implemented red-light cameras have done so by outsourcing the operations and monitoring of the automated systems.

For example, the City of North Miami Beach instituted its Red Light Camera Program by outsourcing to an Arizona-based company who monitored violations through the use of road sensors and photographs; the City retained the right to review these citations, but for the most part, company technicians exercise substantial discretion in issu-

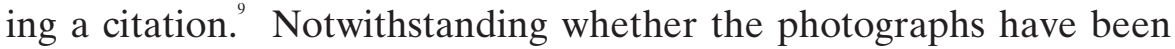
reviewed by a traffic enforcement officer, a citation is issued based on the vehicle's registration information. ${ }^{10}$ Overall, this delegation to private entities, which are usually located outside the state, has been the growing trend for local enforcement of traffic violations.

$6 \quad$ FLA. STAT. $\$ 316.0083$ (2010).

7 See Letter from Charlie Crist, Att'y Gen., to Samuel Goren, City Att'y, Pembroke Pines, Fla. (July 12, 2005), AGO 2005-41, available at www.myfloridalegal.com/ago.nsf/ printview/CE01BE293FCEEA208525703C00720344. [hereinafter Letter from Charlie Crist].

8 See, e.g., Memorandum from Louis Moore, Dir., Purchasing \& Materials Mgmt., to City Council, St. Petersburg, Fla., (Apr. 21, 2011), available at http://www.stpetecameras.org/home/stpete-rlc-contract-with-ats [hereinafter Memorandum from Louis Moore]; CAPITAL Improvements Program, City of MiAmi, Contract By and Between City of Miami \& Am. Traffic Solutions, Inc. to Furnish, Install, Operate, and Maintain a Traffic Infraction Detector Program, Sept. 21, 2010, available at http://www.stpetecameras.org/home/st-pete-rlc-contract-with-ats [hereinafter City of Miami, Am. Traffic Solutions Contract]; OrAngE CNTY. PUB. Works DeP'T, TrAfFic Eng'G Div., Orange Cnty. Gov't Florida Red-Light Running Pilot Project Summary, Draft Final Rep. Submitted to Orange Cnty. Bd. of Cnty. Comm'rs, Nov. 2008 [hereinafter Orange Cnty., Pilot Project Report of Nov. 2008].

9 Letter from V. Lynn Whitfield, City Att'y, N. Miami, to Mayor \& City Council, (May 17, 2011), available at http://www.northmiamifl.gov/Docs/AgendasMinutes/TABF05172011.pdf.

10 See discussion infra note 12.

11 See, e.g., Letter from Edmund T. Baxa, Jr., Foley \& Lardner LLP, to Byron W. Brooks, AICP, Chief Admin. Officer, City of Orlando (Dec. 24, 2007), RFP 07-594, Request for Proposal for Red Light Violation Cameras and Citation System (on file with author); Letter from P.J. Lynch, LaserCraft Representative \& Negotiator, to Althea Pemsel, M.A., C.P.M., Purchasing Agent III, Orlando, Fla., RFP 07-594, Red Light Violation Cameras and Citation System, Protest Responses (Dec. 13, 2007) (on file with author); Letter from James D. Tuton, President, Am. Traffic Solutions, to Jon Mead, C.P.M., Dir. Purchasing, Orlando, Fla., (Dec. 10, 2007), Notice of Protest, RFP No. 07-594, Red Light Violation Cameras and Citation System (on file with author). 
This type of "outsourcing" of law enforcement has regarded these private firms as another arm of the executive branch. Such privatization of law enforcement poses substantial legal issues of municipality authority and administrative agency discretion.

\section{Constitutional Challenges}

Despite the flurry of legal challenges to the automated systems, courts have been relatively reluctant to find the cameras unconstitutional.

Nationwide, judges have generally rejected any claims of constitutional violations. ${ }^{13}$ In theory, the judicial trend against the unconstitutionality of the automated systems is indeed well-founded on and in accordance with the respective jurisprudence of the invoked provisions in any given constitutionally based challenge.

\section{A. Equal Protection}

The Equal Protection Clause prevents state action that infringes on a person's right to be "free from invidious discrimination in statutory classifications and other governmental activity" ${ }^{\prime 14}$ and requires that "all similarly situated persons be treated in a similar manner." These oft-cited "catchphrases" are the touchstone earmarks of the Equal Protection's constitutional requirements. As such, the Court has developed a judicial framework for adjudicating constitutional challenges in a somewhat consistent, straightforward manner to promote clear-cut application.

Essentially, when a statutory classification involves neither a suspect class nor a fundamental right, any constitutional challenge to that

12 See, e.g., Akbar v. Daley, No. 09-cv-1289, 2009 WL 3055322 (N.D. Ill. 2009) (finding state did not violate plaintiff's right to equal protection merely because cameras were installed at some intersections); Williams v. Redflex Traffic Sys, Inc., No. 3:06-cv-400, 2008 WL 782540 (E.D. Tenn. 2008) (finding plaintiff's right to procedural due process was not violated by a $\$ 50$ civil penalty for red-light-camera violation); Idris v. City of Chicago, No. 06-C-6085, 2008 WL 182248 (N.D. Ill. 2008) (finding state's imposing vicarious liability on car owners, but not car dealerships or lessors, did not violate the Equal Protection Clause); Agomo v. Fenty, 916 A.2d 181 (D.C. 2007) (finding state's statutory presumption of liability did not impinge on car owner's right to due process).

13 See sources cited supra note 12.

14 Akbar, 2009 WL 3055322, at 3 (citing Harris v. McRae, 448 U.S. 297, 322 (1980)).

15 Id. (citing City of Cleburne v. Cleburne Living Ctr., Inc., 473 U.S. 432, 439 (1985)).

16 See generally, Yick Wo v. Hopkins, 118 U.S. 356 (1886) (requiring strict-scrutiny standard to cases involving classifications based on race or national origin); Skinner v. Oklahoma, 316 U.S. 535 (1942) (requiring strict-scrutiny standard to cases involving a fundamental right); Loving v. Virginia, 388 U.S. 1 (1967) (requiring strict-scrutiny standard to cases involving racial classification); Craig v. Boren, 429 U.S. 190 (1976) (requiring intermediate-scrutiny standard to sex-based classifications). 
classification must overcome the rational-basis test-the least intrusive and most deferential of the Equal Protection's standards of review. ${ }^{17}$ Therefore, most classifications will pass constitutional muster under the Equal Protection Clause's rational-basis test-unless, of course, the statutory classification is wholly irrational or completely unreasonable.

Based on this framework in the context of red-light camera constitutional challenges, courts have expressly denied the possibility of heightened scrutiny for red-light camera programs: 1) "[t]he freedom to run a red light is not a fundamental right," and 2) "individuals whose vehicles have been photographed violating the red light ordinance" are not members of a suspect class. ${ }^{20}$

Accordingly, the appropriate standard for red-light camera challenges based on the Equal Protection Clause is the rational-basis test; thus, the issue presented is whether the use of automated traffic infraction detectors is rationally related to a legitimate government interest. $^{21}$

In Idris v. City of Chicago, plaintiffs claimed the city's automated system violated the Equal Protection Clause of the United States Constitution because the red-light program provided a defense for car dealerships and manufacturers, yet not to other vehicle owners, "i.e., the defense that a car caught running a red light was formally leased to another person creates a legislative classification that 'lack[s] any rational basis, and render[s] the ordinance invalid on its face.'”

In Idris, the city's ordinance provided that a car dealership or manufacturer could not be vicariously liable for a lessee's violation, whereas other vehicle owners could be vicariously liable for the violation, notwithstanding whether the car's owner was the actual driver at the time of the alleged violation captured by the automated system. ${ }^{23}$

The Idris court applied the rational-basis test for the constitutional challenge since plaintiffs did not, nor could they, argue for heightened scrutiny based on a suspect class or a fundamental right.

17 Id.

18 See generally, Romer v. Evans 517 U.S. 620 (1996) (finding rational-basis test was the least demanding of the Equal Protection tests); Ry Express Agency, Inc. v. New York, 336 U.S. 106 (1949) (finding rational-basis test for most classifications appropriate).

19 Mills v. City of Springfield, No. 2:10-CV-04036-NKL, 2010 WL 3526208, at *6 (W.D. Mo. 2010).

20 Id. at $* 7$.

21 See generally id.; Akbar v. Daley, No. 09-cv-1289, 2009 WL 3055322 (N.D. Ill. 2009); Idris v. City of Chicago, No. 06-C-6085, 2008 WL 182248 (N.D. Ill. 2008).

22 Idris, $2008 \mathrm{WL} 182248$.

23 See id.

24 Id. 
Accordingly, the court acknowledged the standard that plaintiffs face in challenging a red light camera program based on the Equal Protection Clause: "plaintiff[s] attempting to invalidate a statutory classification under the rational basis test face an uphill battle and must "negative every conceivable basis which might support it.","25

In a similarly unsuccessful claim, plaintiffs in Akbar v. Daley challenged the use of automated traffic infraction detectors installed in one part of the city yet not in another part-essentially, an allegedly unconstitutional classification between persons driving in the downtown area of the city and persons driving in the city but outside the downtown area. ${ }^{26}$ The Akbar court characterized the purported classification as "problematic" because persons in both classifications are "constantly ... in flux."

Moreover, since Equal Protection challenges to statutorily created classifications are generally concerned with "legislation whose purpose or effect is to create discrete and objectively identifiable classes," ${ }^{28}$ plaintiffs cannot demonstrate a constitutionally infirm classification since a driver's classification "may be discrete and identifiable at one moment in time . . . but would change from moment to moment"; thus, a driver could "easily transition from protected class to discriminated class by driving a few blocks., ${ }^{29}$

After the Akbar court rejected plaintiffs' classification of drivers affected by the automated systems, the court nonetheless noted plaintiffs' significant burden even if the court accepted plaintiffs' classification claim: unless the municipal ordinance involves members of a suspect class or affects a fundamental right, the municipality need only meet the rational basis standard in order to justify its actions. ${ }^{30}$

Subtly yet distinctively, the Akbar court wholly dismissed the possibility that a suspect class or a fundamental right could possibly exist in this case.

25 See id. at *4 (citing Heller v. Doe, 509 U.S. 312, 319-20 (1993) (quoting Lehnhausen v. Lake Shore Auto Parts Co., 410 U.S. 356, 364 (1973)).

26 Akbar, 2009 WL 3055322, at *3 (citing Enquist v. Oregon Dep’t of Agric., 553 U.S. 591, 601 (2008); San Antonio Indep. Sch. Dist. v. Rodriguez, 411 U.S. 1, 60 (1973) (Stewart, J., concurring) (" $[\mathrm{T}] \mathrm{h}$ e basic concern of the Equal Protection Clause is with state legislation whose purpose or effect is to create discrete and objectively identifiable classes.").

27 Id.

28 Id. (emphasis added by court) (citing San Antonio Indep. Sch. Dist., 411 U.S. at 60 (Stewart, J., concurring)).

29 Id. (citing Enquist, 553 U.S. at 601 and San Antonio Indep. Sch. Dist., 411 U.S. at 60 (Stewart, J., concurring) ("The basic concern of the Equal Protection Clause is with state legislation whose purpose or effect is to create discrete and objectively identifiable classes.").

$30 \quad I d$. at 4.

31 See id. at 6. 
Without a constitutional challenge based on a suspect class or a fundamental right, plaintiffs will almost inevitably face the heavy burden of showing that these automated systems are not rationally based on the state's interest in preventing car crashes caused by red-light running. Accordingly, the rational-basis test is essentially the "roadblock" to a plaintiff's constitutional challenge based on the Equal Protection Clause of the 14th Amendment.

So long as the municipality provides a rational basis for implementing the use of automated infraction detectors, its actions following therefrom will remain relatively unscathed by the necessities of the Equal Protection Clause. The municipality may assert its "rational basis" for red-light cameras without even calling in its legal team: redlight running causes accidents and is illegal. Even if the simplicity of this basis may actually be nothing more than smoke and mirrors, judges are relatively unwilling to delve into the complexities of traffic engineering and statistics.

32 See generally Christine Vendel, Police Study Suggests Red-Light Cameras Don't Add To Safety, THE KANSAS CITY STAR (Jan. 23, 2012), http://www.kansascity.com/ 2012/01/23/3387905/kc-police-study-suggests-red-light.html; James Baxter, Red-Light Cameras Do Not Reduce Right Angle Crashes, NAT'L Motorists Ass'N Blog (Nov. 25, 2008), http://blog.motorists.org/red-light-cameras-do-not-reduce-right-angle-crashes/ (last visited Dec. 22, 2012); Red Light Cameras Linked To Crashes: Red Light Cameras Used To Nab Drivers Who Disobey Traffic Signals Can Lead To More Accidents and Injuries, According To Researchers at The University of South Florida College of Public Health, THE CALGARY HERALD (Mar. 14, 2008), http://www.canada.com/calgaryherald/news/story.html?id=b8a238d6-ab4b-401a-87c2cfd524789502; Red-Light Cameras Increase Accidents: 5 Studies That Prove It, NAT'L MOTORISTS ASS'N BLOG (Jan. 8, 2008), http://blog.motorists.org/red-light-cameras-increase-accidents-5studies-that-prove-it/ (last visited Jan. 26, 2013); Associated Press, Critics Point To Downside of Red Light Monitoring Cameras - Rear-End Accidents, (Sept. 26, 2004), available at http://production.daily-jeff.com/local\%20news/2004/09/27/critics-point-to-downside-of-red-lightmonitoring-cameras-rear-end-accidents. But see Associated Press, Study Finds Red Light Cameras Cut Fatal Crashes (Feb. 1, 2011), http://www.nola.com/traffic/index.ssf/2011/02/ study_finds_red_light_cameras.html; Chuck Squatriglia, Study Says Red Light Cameras Save Lives, WIRED.COM (Feb. 1, 2011), http://www.wired.com/autopia/2011/02/study-says-red-lightcameras-save-lives/; Nedra Pickler, Researchers Find Big Drop in Speeding After Cameras Deployed, AssociATED PRESs, May 1, 2002, available at Associated Press Archive.

33 See, e.g., Idris v. City of Chicago, 552 F.3d 564, 566 (7th Cir. 2009) ("Is it rational to fine the owner rather than the driver? Certainly so. A camera can show reliably which cars and trucks go through red lights but is less likely to show who was driving. ... A system of photographic evidence reduces the costs of law enforcement and increases the proportion of all traffic offenses that are detected; these benefits can be achieved only if the owner is held responsible."); Mills v. City of Springfield, No. 2:10-CV-04036-NKL, 2010 WL 3526208, at *6 (W.D. Mo. 2010) ("Clearly, a legislative body could find that improved surveillance and enforcement of red light violations would result in fewer accidents."); Akbar v. Daley, No. 09-cv-1289, 2009 WL 3055322, at *4 (N.D. Ill. 2009) ("Because Defendant has presented possible reasons that would justify the classification and Plaintiff has failed to "allege facts sufficient to overcome the presumption of rationality,' Plaintiff's equal protection challenge must fail.") (citing Wroblewski v. City of Washburn, 965 F.2d 452, 460 (7th Cir. 1992); Shavitz v. City of High Point, 270 F. Supp. 2d 702, 715 
Therefore, plaintiffs challenging the constitutionality of automated traffic infraction detectors must establish that the rational basis of traffic safety can somehow outweigh an individual's interest in paying the civil penalty for an infraction or appealing the authenticity of photographic evidence of an alleged red-light violation. Such an argument has not been made; arguably, such an argument cannot be made because the safety of drivers carries substantially more weight than any single individual interest.

\section{B. Due Process}

Generally, based on the Supreme Court's pronouncement in Mathews v. Eldridge, in order to determine whether a state's procedures adequately provide due process, a trial court will apply the three-prong Mathews balancing test: 1) whether an individual's interest is affected by state action; 2) whether the procedure used increases the risk of erroneously depriving this interest, and if so, whether an alternative or additional procedural safeguard yields a more probable value; and 3) whether an additional safeguard imposes a burden on the state's fiscal and administrative interest."

Although figuratively referred to as a "balancing test," where the individual's interest is weighed against the government's interest, the notion of balancing in this context is essentially placing a mouse and an elephant on opposite ends of a playground seesaw.

In Williams v. Redflex Traffic Systems, Inc., plaintiffs filed suit against Redflex Traffic Systems, Inc., a private company, as well as the city contracting with the company. ${ }^{35}$ Plaintiffs claimed the city's redlight-camera program violated their constitutional right to due process. $^{36}$ Without reaching the issue of the actual red light camera system underlying the claim, the Tennessee appellate court addressed the appropriate standard applied for such a claim:

In order to state a claim for denial of procedural due process, a plaintiff must first establish that she has been deprived of a property or liberty interest. In this case, the property interest at issue presumably lies in the $\$ 50$ 'civil penalty' that was assessed against [plaintiffs].

\footnotetext{
(M.D.N.C. 2003) ("Defendants [the City] have put forth significant evidence indicating that the goal of the ordinance is to promote public safety.").

34 Mathews v. Eldridge, 424 U.S. 319, 335 (1976).

35 Williams v. Redflex Traffic Sys., Inc., No. 3:06-cv-400, 2008 WL 782540, at *2 (E.D. Tenn. 2008).

$36 \quad I d$. at $* 3$.

37 Id. at *4 (citing Bd. of Regents of State College. v. Roth, 408 U.S. 564, 569 (1972)).
} 
Accordingly, the court rejected plaintiffs' argument that the violations violated their right to due process, finding that the plaintiffs' purported property interest could not outweigh the state's interest in traffic safety.

Similarly unsuccessful, plaintiffs in the District of Columbia claimed a due process violation based on the state's statutory scheme for issuance and appeal of citations issued by the automated systems. ${ }^{39}$

In Agomo v. Fenty, the red-light-camera program in question bears substantial similarity to the general standardized approach to issuance of citations in most states that have permitted the use of automated systems: based on the owner-responsibility scheme, the owner of the vehicle received a notice of the infraction captured by the cameras; the notice informs the vehicle owner that he shall be liable for payment of the citation unless he could provide evidence that his vehicle was in the custody or control of another person; further, the notice must provide the date, time, location, license plate number, and the photo images showing the violation occurred; and, after receiving the notice, the vehicle owner could request a hearing to appeal the citation; however, failure to pay or otherwise appeal constituted an admission of liability.

Challenging this standard approach, plaintiffs in Agomo alleged a due process violation based on the "presumption of guilt" in the owner-responsibility scheme. ${ }^{41}$ [Although not addressed in the court's opinion, plaintiffs' use of the word "guilty," in and of itself, is misplaced. The issue of civil liability versus criminal guilt is a dispositive distinction and is discussed in greater detail below.]

In order to determine whether plaintiffs' due process rights had been violated by the red-light-camera program, the court found that, under the Mathews balancing test, plaintiffs' due process rights were not violated because of a failure to provide notice or a deprivation of the opportunity to be heard. ${ }^{42}$ The court explained that "(a) the plaintiffs received notices of infraction in advance of any determinations of

38 Id.

39 Agomo v. Fenty, 916 A.2d 181 (D.C. 2007).

40 See, e.g., City of Miami, Am. Traffic Solutions Contract, supra note 8; AMERICAN Traffic Solutions, Contract Between City of Ocoee \& Am. Traffic Solutions, Inc. Pertaining to Red Light Running Camera Enforcement System, July 23, 2010 [hereinafter City of Ocoee, Am. Traffic Solutions Contract]; AMERICAN TrafFic Solutions, Contract Between City of Ft. Lauderdale \& Am. Traffic Solutions, Inc., July 7, 2010 [hereinafter City of Ft. Lauderdale, Am. Traffic Solutions Contract].

41 Agomo, 916 A.2d at 188.

42 Id. at 190. 
liability, (b) that the notices contained an accurate identification of the vehicle, and (c) a clear description of the asserted violation." ${ }^{43}$

The Agomo court noted that the plaintiffs' due process challenge was not based on the procedure for issuance and appeal of a citation, but rather that the program "instead creates a statutory presumption of liability, whereby the identity of the driver is irrelevant, and that this system therefore violates due process and conflicts with the requirements in other sections of the traffic code that require the identity of the driver to be proved before liability can be assessed." ${ }^{\text {"4 }}$ Ultimately, the court found that the statute created a rebuttable presumption of vicarious liability and, accordingly, noted that "the Supreme Court has long held that on their face, systems of vicarious liability that impose civil liability are not contrary to the notions of due process." ${ }^{45}$

The Agomo court referred to the plaintiff's interest as a "modest fine," whereas the government emphatically asserted its interest in preventing traffic accidents and ensuring safety on its roadways. ${ }^{46}$ This notion of balancing interests is commonly and consistently invoked in courts nationwide. Since the public outcry against the red light programs has focused on the individual's rights, judges could consistently and steadfastly reject individual constitutional challenges.

\section{Civil Versus Criminal Offenses}

Since a state may exercise its police power to regulate and maintain traffic safety, a state may also exercise its power to identify conduct threatening traffic safety and to characterize such conduct as a civil or criminal offense. Notwithstanding the traditional common-law principles of criminal law, a municipal code infraction may constitute a criminal offense in one state yet constitute a civil offense in another. Therefore, the cases arising from statutory implementation of redlight cameras vary markedly nationwide based on whether the enabling legislation defines a red-light violation as criminal or civil in nature.

In the context of automated traffic-infraction systems, the distinction between a civil and a criminal penalty is crucially determinative, insofar as such a distinction variedly implicates different constitutional requirements. This civil-criminal distinction is crucial because "[i]f the penalty is indeed criminal, then a panoply of federal constitu-

\footnotetext{
Id.

Id. at 191.

Id. at 193 .

Id.
} 
tional rights, including rights to confrontation and rights against selfincrimination, arise." ${ }^{47}$ Basically, whether an infraction captured by a red-light camera constitutes a civil or criminal offense determines the nature and extent of the process due to the alleged violator.

Generally, municipal code citations, such as parking tickets, are classified as civil in nature and, thus, municipalities "need not provide the heightened procedural protections required by the Fifth, Sixth, and Eighth Amendments" of the Constitution. ${ }^{48}$ However, a traffic citation, such as a moving violation, may be classified as a criminal offense and, as such, implicate the requirements of the Fifth Amendment's protection from self-crimination, the Sixth Amendment's right to confront one's accusers, and the Eighth Amendment's proscription of cruel and unusual punishment. ${ }^{49}$

Upon receiving citations for violations captured by red-light cameras, petitioners in Shavitz v. City of High Point challenged a city ordinance implementing "traffic control photographic systems" authorized by state legislation. ${ }^{50}$ The enabling act permitting such an ordinance required that violations detected by photographic systems "be deemed a noncriminal violation for which a civil penalty of fifty dollars (\$50.00) shall be assessed...."

In determining whether monies collected for violations captured by red-light cameras constituted a criminal or civil penalty, the Shavitz court dismissed the argument that such a distinction could be based on whether the ordinance referred to the $\$ 50.00$ assessment as a "fine" or a "penalty." The court found the more significant analysis must require more than the labels attached to the violation. Accordingly, the court emphasized: "The crux of the distinction lies in the nature of the offense committed, and not in the method employed by the municipality to collect fines for the commission of the offense.".54

Nonetheless, the Shavitz court disregarded as "immaterial" the fact that a violation of the red-light ordinance was also a violation of the state statute, which provided that red-light running was unlawful. Moreover, the court found that, notwithstanding whether the violation is punishable as an infraction, subject to state penalty, or as a civil as-

Williams v. Redflex Traffic Sys., Inc., No. 3:06-cv-400, 2008 WL 782540, at*4 (E.D. Tenn.

City of Creve Coeur v. Nottebrok, 356 S.W.3d 252 (Mo. Ct. App. E.D. 2011).

See generally Williams, 2008 WL 782540.

Shavitz v. City of High Point, 270 F. Supp. 2d 702 (M.D.N.C. 2003).

Id. at 713 .

Id.

Id. at 712 .

Id. at 728 (citing Cauble v. Asheville, 271 S.E.2d 258, 260 (1980)).

Id. at 715 
sessment, subject to city penalty, "monetary payments are nevertheless 'imposed to deter future violations and to extract retribution from the violator' for [his] transgression."

Ultimately, the Shavitz court held the $\$ 50.00$ assessment constituted a civil penalty. ${ }^{57}$ In contrast to the majority of courts determining the proper distinction of a given violation, the Shavitz court's characterization of the distinction between criminal and civil penalties was seemingly result-driven, considering the state's constitution required municipalities to allocate a portion of the proceeds of civil penalties to the state's educational system.

Notwithstanding the anomalous Shavitz analysis, the majority of cases identifying the distinction between civil and criminal offenses invoke the oft-cited Supreme Court analysis in Kennedy v. MendozaMartinez. ${ }^{59}$ In order to determine whether the penalty for photocaptured, red-light infractions is civil or criminal, courts have applied what has been referred to as the "Mendoza-Martinez" factors: 1) whether the penalty "involves an affirmative disability or restraint"; 2) whether such penalty has "historically been regarded as punishment"; 3) whether it depends on a "finding of scienter"; 4) whether it operates to "promote the traditional aims of punishment-retribution and deterrence"; 5) whether the penalized conduct is "already a crime"; 6) whether the penalty has "an alternative purpose to which it may rationally be connected"; and 7) whether it "appears excessive in relation to the alternative purpose assigned."

Considering these factors in order to determine whether the sanction imposed for photo-captured infraction is for a civil or criminal violation, the court in Mills v. City of Springfield found that the red-light sanction did not "impose a physical restraint but merely a monetary penalty" and that such penalty "does not resemble the punishment of imprisonment, which is the paradigmatic affirmative disability or restraint." ${ }^{, 1}$ In swiftly glossing over the first and second Mendoza-Martinez inquiries, the court found that the penalty imposed

\footnotetext{
Id. (citing North Carolina Sch. Bds. Ass'n v. Moore, 614 S.E.2d 504, 517 (N.C. 2005)).

Id. at 716-17.

Id. at 724

372 U.S. 144, 168-69 (1963). See, e.g., Hudson v. United States, 522 U.S. 93 (1997); City of Creve Couer v. Nottebrok, 356 S.W.3d 252, 258 (Mo. Ct. App. E.D. 2011); Mills v. City of Springfield, No. 2:10-CV-04036-NKL, 2010 WL 3526208, at *8 (W.D. Mo. 2010); Kilper v. City of Arnold, No. 4:08cv0267 TCM, 2009 WL 2208404, at *13 (E.D. Mo. 2009); Mendenhall v. City of Akron, Nos. 5:06 CV 139, 5:06 CV 154, 2008 WL 7484179, at*3 (N.D. Ohio 2008).

60 Mills, 2010 WL 3526208, at *8 (citing Hudson v. United States, 522 U.S. 93 (1997); Kennedy v. Mendoza-Martinez, 372 U.S. 144, 168-69 (1963)).

61 Mills, 2010 WL 3526208, at *9 (citing Smith v. Doe, 538 U.S. 84, 86 (2003)).
} 
was a "mere $\$ 100$ fine,", and that "[m]oney penalties have not historically been viewed as punishment."

In terms of the other Mendoza-Martinez factors, the inquiry as to whether the sanction will "promote the traditional aims of punishment-retribution and deterrence" is the "lone factor that cuts in favor of [plaintiffs] as to suggest that the ordinance is criminal in nature." Nonetheless, the "mere presence of a [deterrent] purpose is insufficient to render a sanction criminal, as deterrence 'may serve civil as well as criminal goals." ${ }^{65}$ Furthermore, according to the Mills court, because such sanctions do not require a showing of scienter, the mere penalty cannot reasonably be intended as retribution. ${ }^{66}$

In considering the "alternative purpose" inquiry of the MendozaMartinez factors, the Mills court exercised judicial restraint by deferring to the legislature: "[c]learly, a legislative body could find that improved surveillance and enforcement of red light violations would result in fewer accidents." ${ }^{67}$ Nevertheless, in the court's view, even if the use of red-light cameras does not actually promote its purpose, the sanction is not deemed punitive merely because it lacks a perfect or even close fit. ${ }^{68}$ Accordingly, the Mills court found the use of traffic infraction detectors is "rationally connected to the legitimate nonpunitive purpose of reducing traffic accidents at traffic light intersections." ${ }^{69}$

The Mills court's gloss-over of the Mendoza-Martinez factors, and its characterization of the "mere" penalty and the "mere" fact that it lacks a perfect, or even close, fit to its purpose of promoting public safety, are clear indicators of the court's inclination towards legislative deference in the context of challenges to the use of red-light camera. ${ }^{70}$ Arguably, this trend reflects the underlying notion of judicial restraint, wherein courts have been consistently reluctant to second-guess the legislature's decision to implement automated traffic infraction detectors.

However, does this judicial trend necessarily assert that automated systems are here to stay? Insofar as the civil-criminal distinction, legislative entities can steer clear of any serious constitutional

\footnotetext{
Id. (emphasis added).

Id. at $* 10$.

Id. (citing Shavitz v. City of High Point, 270 F. Supp. 2d 702, 715 (M.D. N.C. 2003)).

Id. (citing Hudson v. United States, 522 U.S. 93, 105 (1997)) (emphasis added).

Id. (citing Kansas v. Hendricks, 521 U.S. 346, 362 (1997)).

$I d$. at *7.

Id. at *11 (citing Smith v. Doe, 538 U.S. 84, 103 (2003)).

Id. at *11 (citing Kilper v. City of Arnold, 2009 WL 2208404, at*17 (E.D. Mo. 2009)).

7 See id.
} 
infirmities by imposing sanctions expressly labeled as "civil" in nature, eliminating the stricter requirements attached to criminal sanctions.

Specifically, by imposing civil, non-punitive sanctions for photocaptured violations, the state avoids the implications of criminal liability: 1) the Confrontation Clause is inoperative, notwithstanding, after all, that the alleged violator cannot confront his "accuser" — the camera that captured his violation; 2) the Fifth Amendment's protection against self-incrimination is inoperative, insofar as incrimination necessarily involves underlying conduct that is criminal in nature; and 3) the Due Process Clause requires a markedly lesser degree of "process" in the context of civil infractions.

Arguably, the implementation of automated traffic systems may pass constitutional muster in terms of violations of individual rights, yet the legal inquiry does not reach a dead-end merely because the automated systems themselves are theoretically constitutional. The issue turns on the complexities of administrative law and the intrastate relations of local governments, law enforcement and private companies.

Although the majority of challenges to the use of automated traffic detectors have focused on individual rights, a few, rare challenges have been raised against a state or local authority for entering into a contract with a private third party. ${ }^{71}$ In two factually similar cases, plaintiffs filed suit against ACS State and Local Solutions, Inc., the company providing "traffic signal enforcement systems to municipali-

71 See, e.g. Travelers Prop. Cas. Co. of Am. v. Nassau Cnty. Traffic \& Parking Violations Agency, 34 Misc.3d 844, 849 (N.Y. Sup. Ct. 2011) ("If the insurance company wishes to obtain information gathered through the Red Light Camera Program in anticipation of future litigation, it may do so at their own expense directly through the vendor."); People v. Daugherty, 199 Cal. App. 4th Supp. 1, 4 (Cal. App. Div. Super. Ct. 2011) (finding the "cost-neutrality" provision of contract between city and Redflex Traffic Sys., Inc. improperly incentivized issuance of citations by compensating the company based on the number of citations generated); Wiles v. Ascom Transp. Sys., Inc., No. 3:10-CV-28-H., 2011 WL 672652, at *3 (W.D. Ky. 2011) (rejecting argument that company was a private actor acting as a state actor "under color of law"); Jadeja v. Redflex Traffic Sys., Inc., 764 F. Supp. 2d 1192, 1196 (N.D. Cal. 2011) (rejecting plaintiffs' challenge based on an alleged "legally protected interest in freedom from unfair or unlawful business practices which led to the inclusion of the cost-neutral clause in the contract between Redflex and Menlo Park”); Kennedy v. Polumbo, 704 S.E.2d 916, 925 (N.C. Ct. App. 2011) (ruling in favor of city and private company, asserting that "it is immune as a matter of law because it installed the red-light camera with proper care and skill pursuant to its contract with the City"); Ward v. ACS State \& Local Solutions, Inc., 328 S.W.3d 648, 653 (Texas App. 2010) (finding summary judgment was appropriate because plaintiffs failed to establish company's "failure to acquire a license would or could have any exclusionary effect on the admissibility of the evidence concerning the red light violation"); Verrando v. ACS State \& Local Solutions, Inc., No. 3:08-CV-2241-G., 2009 WL 2958370 , at $* 4$ (N.D. Tex. 2009) (finding plaintiffs failed to establish causal connection between company's failure to acquire license and plaintiffs' alleged injury). 
ties," asserting negligence per se based on the company's failure to acquire the proper occupational license required by state law. ${ }^{72}$

Whereas most challenges are filed by an alleged violator who outright denies liability, plaintiffs in Verrando and Ward did not contest their respective violations and the consequential fine imposed, nor did they challenge the accuracy of the company's automated systems that captured their cars in the intersection after the traffic signals had turned to red. ${ }^{73}$ Rather, plaintiffs argued that the photographs were impermissible evidence since the company did not have the state-mandated occupational license for an entity that acts as an "investigations company." ${ }^{74}$

Essentially, in both Verrando and Ward, plaintiffs arguments were "premised on the notion that, but for the operation of the ACSinstalled, red-light camera, no citation would have been issued." Ironically, and unsuccessfully, plaintiffs attempted to establish the company's liability by asserting the injury they suffered - the civil fine imposed - occurred when they unlawfully ran a red light. ${ }^{76}$ The courts rejected such claims by stating matter-of-factly: "[P]laintiffs do not have a legally protected right to engage in illegal conduct and be free from the consequences." ${ }^{, 77}$

Ultimately, plaintiffs' unsuccessful attempts to exclude evidence acquired through the unlicensed company's automated camera system were fatal-by-design: in order to avoid the civil penalty imposed for photo-captured infraction, plaintiffs emphatically focused on the company's failure to comply with the state's occupational code, while simultaneously disregarded their liability for the actual violation underlying the entire claim. ${ }^{78}$

Notwithstanding the obvious infirmity of challenging automated camera systems without contesting the infraction issued therefrom, plaintiffs have filed suit, albeit ultimately unsuccessfully, against municipalities based on their contractual relationship with a private company to operate the entire red-light-camera program, including not

\footnotetext{
See Ward, 328 S.W.3d 648; Verrando, 2009 WL 2958370.

See sources cited supra note 72.

Ward, 328 S.W.3d at 651 (citing TeX. OCC. CODE AnN. § 1702.101 (2004) ("Chapter 1702 requires that any person who acts as an 'investigations company' obtain an investigations com-

75 Ward, 328 S.W.3d at 652; see also Verrando, 2009 WL 2958370.

76 See sources cited supra note 75.

77 Verrando, 2009 WL 2958370, at *3 (citing Bell v. Redflex Traffic Sys., Inc., No. 4:08-CV444-MHS-DDB, at 5 (E.D. Tex. Mar., 25, 2009) (unpublished opinion)).

78 Id.
} pany license.")). 
only installation and maintenance, but also image review, issuance of citations, and collections of fines imposed for violations.

Plaintiffs in Leonte alleged that the private company performed all the tasks of the automated program without any involvement by the city. ${ }^{80}$ However, the court rejected the argument based on the contract with the city that showed it "retains the right to "monitor, evaluate, and provide guidance to the CONTRACTOR in the performance of' the contract and 'the right of access to all activities and facilities operated by the CONTRACTOR under this Agreement' and to 'all files, records, and other documents related to the performance of this Agreement.","

Although the Leonte court ultimately upheld the contract's validity as it pertained to plaintiffs' due process claim, the court did not necessarily delve into the issue of whether the city's "retaining the right" actually had legal force or was merely a passive "right" that could be invoked at the whim of a city official, yet otherwise a dormant right that was neither required nor necessarily invoked during the duration of the contract.

\section{FLORIDA'S TRAFFIC SAFETY ACT}

The Mark Wandall Traffic Safety Act enables "local departments, municipalities, and agencies" to implement automated trafficenforcement technology, namely, red-light cameras. ${ }^{83}$ Interpreting the Act broadly, a majority of local authorities have contracted with private, third-party contractors to install, maintain, and/or operate red-

79 See, e.g., Leonte v. ACS State \& Local Solutions, Inc., 123 Cal. App. 4th 521, 528 (2d Cal. Ct. App. 2004).

80 Id.

81 See id. at 527 ("We believe that the statutory purpose of authorizing the use of automated traffic enforcement systems is best served by a construction of 'operate' that allows a governmental agency to hire private contractors to perform a broad range of functions. We therefore conclude that former Vehicle Code section 21455.5 did not prohibit a governmental agency from hiring a private company to perform functions in connection with the operation of an automated traffic enforcement system provided that the governmental agency retained the right to oversee and control the functioning of the system and thereby ultimately was the system operator. A governmental agency retains the right to oversee and control the functioning of the system if it retains the right to ensure satisfactory performance through such means as the right to inspect, the right to make suggestions as to the details of the contractor's performance, and the right to terminate the contract.").

82 See id. at 526 ("The parties dispute the meaning of the italicized language and particularly the meaning of the word 'operate,' which former Vehicle Code section 21455.5 did not define." "Former Vehicle Code section 21455.5 (Stats. 2001, ch. 496, § 1) authorized the use of automated traffic enforcement systems at intersections where drivers are required to stop. Subdivision (a) of the statute stated in part, '[o]nly a governmental agency, in cooperation with a law enforcement agency, may operate an automated enforcement system.'”).

83 FLA. STAT. $\$ 316.0083$ (2010). 
light-camera programs. ${ }^{84}$ Although some local authorities have enacted ordinances to limit the discretion of these private entities, other local authorities, including major metropolitan areas such as the City of Miami, have entered into agreements that delegate substantial discretion to private entities located outside the State of Florida.

Although the legislature contemplated the presence of private contractors in the initial implementation of the red-light programs within the enactment of the Act, this mere presence cannot be said to encompass the role of the private contractor as has been broadly construed by individual municipalities and counties.

\section{A. Legislative Intent}

The question is: did the Florida Legislature intend for "local departments, municipalities, and agencies" to also include a delegation of similar authority to "manufacturers and vendors" referred to elsewhere in the Act?

The role of "vendors and manufacturers" $"$ within the definition of the Act was intended to refer to the companies supplying and installing the equipment. Further, in some cases, the role of the vendor and/or manufacturer may, in fact, exist beyond the initial installation, but this continued relationship between the vendor or manufacturer, and the municipality or county, was intended for purposes of "maintenance" of the equipment hardware itself. ${ }^{87}$

In analyzing the fiscal impact of the Act on local governments, the legislature acknowledged the possibility for the municipality or county to contract with a private vendor:

If local governments choose to enact ordinances to permit the use of traffic infraction detectors, there will be a fiscal impact to the local governments for the cost of the installation and maintenance of the devices. The impact will vary depending on the ne-

84 See, e.g., Memorandum from Lisa R. Rhea, P.E., Dir. Pub. Works, to Bruce T. Haddock, City Mgr., Oldsmar, Fla. (Nov. 30, 2011), available at http://www.myoldsmar.com/ Pages/Agendas/OldsmarFL_CouncilAgendas/12062011/Item005.pdf [hereinafter Memorandum from Lisa R. Rhea]; Memorandum from Alex Rey, Town Mgr., to Mayor \& Town Council, Miami Lakes, Fla. (July 12, 2011), available at http://www.miamilakes-fl.gov/pdfs/Agendas/2011/2011-0712-agenda-packet.pdf [hereinafter Memorandum from Alex Rey]; Memorandum from Louis Moore, supra note 8; City of Miami, Am. Traffic Solutions Contract, supra note 8; Orange Cnty., Pilot Project Report of Nov. 2008, supra note 8.

85 E.g., City of Miami, Am. Traffic Solutions Contract, supra note 8.

86 FLA. STAT. $\$ 316.0083$ (2010).

87 See, e.g., H.R. StAFF ANAlYSIS, Mar. 9, 2010, H.R. 325, 2010 Reg. Sess. (Fla. 2010). 
gotiated agreement between the local government and any private vendor providing equipment.

This pre-enactment recognition of private vendors providing equipment was eventually sanctified in the Uniform Traffic Control Code's provision for "transitional implementation" of automated infraction detectors after enactment of the Act. ${ }^{89}$ The provision initially sets forth the general mandate for post-enactment implementation of the systems, insofar as "any traffic infraction detector deployed on the highways, streets, and roads of [the] state must meet specification established by the Department of Transportation. ..."

However, recognizing the pre-enactment installation of such automated detectors, the "transitional implementation" legislative mandate includes two exemptions for any equipment, either: 1) "acquired by purchase, lease, or other arrangement under an agreement entered into by a county or municipality on or before July 1, 2011"; or 2) "used to enforce an ordinance enacted by a county or municipality on or before July 1, 2011." Accordingly, if such exemptions apply, the equipment is "not required to meet the specifications established by the Department of Transportation until July 1, 2011."92

Based on the legislative history and subsequent legislation therefrom, the Act intended for manufacturers and/or vendors to provide the automated detector equipment, as well as the possibility to ensure its functionality after the initial installation, whereas the "operation" and "implementation" of the system remained rightfully within the authority of the local government yet limited by the Department of Transportation's discretion to prescribe and establish specifications for uniform operation of such automated systems.

Aside from the actual traffic-infraction detectors, namely, the equipment hardware itself, the continued role of the vendor and/or manufacturer was not necessarily contemplated or intended when the Act was presented before the legislature. ${ }^{94}$ Specifically, the bills pro-

88 Id. (emphasis added).

89 FLA. STAT. § 316.07456 (2010).

90 Id.

91 Id.

92 Id.

93 Compare Fla. Stat. § 316.0083 (2010) with H.R. StafF AnAlysis, Apr. 26, 2011, H.R. 149, Reg. Sess. (Fla. 2011); H.R. StAFF AnAlysis, Apr. 13, 2010, H.R. 325, Reg. Sess. (Fla. 2010); H.R. StafF AnAlysis, Apr.. 19, 2010, H.R. 325, Reg. Sess. (Fla. 2010); and S. BILl AnAlysis \& FisCAL IMPACT STATEMENT, Apr. 14, 2010, S.B. 2166, Reg. Sess. (Fla. 2010).

94 See generally H.R. STAFF ANALYSIS, Apr. 26, 2011, H.R. 149, 2011 Reg. Sess. (Fla. 2011); H.R. STAFF ANALYSIS, Apr. 13, 2010, H.R. 325, 2010 Reg. Sess. (Fla. 2010); H.R. STAFF ANALYSIS, Apr. 19, 2010, H.R. 325, 2010 Reg. Sess. (Fla. 2010); S. BILl ANAlysis \& FisCAL IMPACT StATEMENT, Apr. 14, 2010, S. 2166, 2010 Reg. Sess. (Fla. 2010). 
posed various provisions that referred explicitly to the governmental entity, not a private vendor or contractor. ${ }^{95}$ Moreover, the ordinances enacted based on the enabling legislation rarely, if ever, make any mention of a private, third-party vendor, even though the municipalities engaging in pre-ordinance discussion, at the very least, contemplated the use of private companies.

\section{Statutory Requirements For State Entities Awarding Contracts}

Based on the legislative history, the legislature acknowledged the existence of pilot programs used to ascertain data in order to select a given intersection based on statistical proof. However, even in these cases, the legislative history is silent as to the vendor and/or manufacturer of the equipment having any role in the collection of such data, and certainly not in any subsequent contracts, for the continued role of the private entity once the pilot programs ceased.

Nonetheless, based on the procedural safeguards set forth in statutes directly regulating the contract bid process, the legislature expressly rejected the role of private contractors in the selection process wherein the participants have any interest in the selection of a given bid proposal.

The Orange County Pilot Project did not install the cameras to issue tickets for the violations captured by the new systems, but merely to evaluate the effectiveness of the system and its implementation." "The study objectives were to validate the severity of red-light running in Orange County, test public reaction, and quantify needed resources." ${ }^{100}$ Taken individually and collectively, these objectives are empty assertions for a study that, at best, could possibly provide evaluative value as to the prevalence of red-light violations at any given intersection. Arguably, the study itself was result-driven from its nascence.

After submitting its contract proposal to the county, American Traffic Solutions, Inc., a Scottsdale-based corporation, was awarded the contract in order to "design, furnish, and assist with installation and operation of video detection cameras at all approaches of the five

95 Id.

96 See discussion infra Part III.B (comparing municipality interpretation of the Act and the subsequent ordinances enacted therefrom).

97 See discussion infra Part III.B (providing details of city commission meeting and the resolution to approve a contract between the city and a private company).

98 FLA. STAT. § 334.193 (2010).

99 Orange Cnty., Pilot Project Report of Nov. 2008, supra note 8.

100 Id. 
selected intersections." ${ }^{, 101}$ This familiar contract language, often referred to as the "scope" of a private corporation's red-light systems, appears in some form or another in almost any given contract between local government and the third-party contractors for the operation of red-light cameras. ${ }^{102}$

The approach taken in Orange County was prior to the enactment of the Traffic Safety Act, which could explain the reason for a "study" that did not issue tickets or even take photographs or video. "No video recording or snapshot photos [were] taken and no citations were issued." ${ }^{103}$

Interestingly, at the pre-Traffic Safety Act phase, ATS strategically sowed the seed for the future legislative authorization of the redlight programs. When the Florida Legislature finally enacted the Act, "Orange County selected American Traffic Solutions, Inc. (ATS) based in Scottsdale, Arizona to install the photo enforcement system since this same vendor installed cameras for the red-light running detection study. Use of the same vendor provided a cost savings for the County."104

Essentially, the company providing the data to determine whether red-light programs should be enforced was the same company that would eventually operate the program whenever such systems became legal and, thus, profitable - provided that the company's data indicated the programs should be enforced.

Undoubtedly, the county appropriately asserts "cost savings" its reason for granting ATS the contract to enforce the program; however, and more significantly, the county does not indicate any concern with the authenticity and objectivity of the study and its results. Basically, as ATS lobbyists worked the legislators in Tallahassee, ATS contractors were fervently placing themselves in all the right places for the "right time" to come - enactment of the Act. ${ }^{106}$

In section 334.193 of the Florida Statutes (2010), dealing with transportation administration, the legislative mandate expressly prohibits participation in the bidding process by certain persons with financial interests in the purchase, sale and/or selection of contract bid

101 Id.

102 See, e.g., Memorandum from Lisa R. Rhea, supra note 84; Memorandum from Alex Rey, supra note 84; Memorandum from Louis Moore, supra note 8; City of Miami, Am. Traffic Solutions Contract, supra note 8; Orange Cnty., Pilot Project Report of Nov. 2008, supra note 8.

103 Orange Cnty., Pilot Project Report of Nov. 2008, supra note 8.

104 Id.

105 Id.

106 LOBBying FIRM COMP. REP. BY PRINCIPAL, available at http://olcrpublic.leg.state.fl.us (Fla. 2008). 
proposals between a governmental entity and private contractor. ${ }^{107}$ The legislative prohibition states:

(1) It is unlawful . . . for any company, corporation or firm in which ... an employee ... has a financial interest, to bid on, enter into, or to be personally interested in: (a) [t]he purchase or furnishing of any materials or supplies to be used in the work of the state; (b) [a] contract for ... the performance of any other work for which the department is responsible.

Based on this statutory provision, ATS is undisputedly a corporation/company/firm, notwithstanding its role in the operation of redlight-camera programs. In this capacity, ATS was hired to implement the pilot program in Orange County, prior to any legislative enactment allowing issuance of citations for red-light violations.

Initially, ATS' role in the pilot program was to collect statistical data in order for the county to decide whether a red-light program would be appropriate within the county at any given intersection. Nonetheless, ATS purchased and/or furnished the equipment for the pilot program and, subsequently, furnished the equipment in its operation of the red light camera programs once the legislature enacted its usage in the issuance of citations. ${ }^{109}$

Throughout its existence within Orange County, ATS was financially interested in the implementation and continued operation of a red-light camera program. However, whereas its initial role in the pilot program was purportedly "objective," insofar as its role was to ascertain statistical data, ATS' subsequent role in contracting with the county was based on the company's assessment that a red light camera program would be beneficial to the county.

Where the lines of objectivity and substantial fiscal interests are intertwined as such, any private company could hardly be objective if the outcome of its data is dependent on its future as a potential contractor with the county.

\section{Statutory Requirements For Uniform Traffic Code}

The Florida Legislature adopted Chapter 316 of the Florida Statutes, commonly known as the "Uniform Traffic Code" ("Code"), for the legislative purpose of providing uniform application of traffic laws throughout the State and its counties and of traffic ordinances in its

107 FLA. STAT. § 334.193 (2010)

108 Id.

109 Orange Cnty., Pilot Project Report of Nov. 2008, supra note 8. 
municipalities. $^{110}$ Notwithstanding whether the state entity is a municipality or county, the Code includes the following proviso applicable to all local governmental entities: "It is unlawful for any local authority to pass or to attempt to enforce any ordinance in conflict with the provisions of this chapter."

Contained within the Code, the legislature specifically enumerated the proper scope of a municipality's authority to control traffic in their respective jurisdictions. ${ }^{112}$ Among the legislative directive, section 316.008 of the Code provides explicit parameters for the local authorities' exercise of its police powers, ${ }^{113}$ acknowledging the interrelations of other state entities and their respective ability to regulate traffic ${ }^{114}$ while upholding the Code's purpose of uniform application throughout the entire state, regardless of jurisdiction. ${ }^{115}$

Section 316.008(1) delegates qualified power to the local authorities, wherein the Code is intended to provide the minimum statutory requirements necessary for uniform application of traffic laws, but not intended to prevent local entities from regulating streets and highways within their respective jurisdictions and with their reasonable exercise of police power.

Among the enumerations contained in section 316.008(1) for the power of local entities, the Code includes the following permissible exercise of local authorities: "(b) Regulating traffic by means of police officers or official traffic control devices.... (w) Regulating, restricting, or monitoring traffic by security devices or personnel on public streets and highways, whether by public or private parties and providing for the construction and maintenance of such streets and highways." ${ }^{117}$

In order to maintain the Code's purpose of uniformity, section 316.008(8) addresses the specific guidelines for local entities operating automated traffic infraction detectors pursuant to the Traffic Safety

110 FLA. STAT. $\$ 316.002$ (2011).

111 Id.

112 Id.

113 As defined in section 316.003, the term "[1]ocal authorities," as it appears within Chapter 316, including the Uniform Traffic Code and the Traffic Safety Act, includes "all officers and public officials of the several counties and municipalities of this state." FLA. STAT. $§ 316.003(20)$ (2010).

114 As defined in section 316.003, the term "official traffic control devices," as it appears within Chapter 316, including the Uniform Traffic Code and the Traffic Safety Act, is defined as: "All signs, signals, markings, and devices, not inconsistent with this chapter, placed or erected by authority of a public body or official having jurisdiction for the purpose of regulating, warning, or guiding traffic.” FLA. STAT. § 316.003(23) (2010).

115 FLA. STAT. § 316.008 (2011).

116 FLA. STAT. § 316.008(1) (2011).

117 FLA. STAT. $\$ \S 316.008(1)(\mathrm{b}),(1)(\mathrm{w})$ (2011). 
Act. ${ }^{118}$ This section begins with the legislature's initial recognition that a county or municipality may implement the use of traffic infraction detectors pursuant to section 316.0083 of the Florida Statutes. ${ }^{119}$ Immediately thereafter, the legislature included the following qualifications for the use of traffic-infraction detectors ${ }^{120}$ : “Only a municipality may install or authorize the installation of such detectors" within the incorporated areas of the municipality, and "only a county may install or authorize the installation of such detectors" within the unincorporated areas of the county.

Undoubtedly, as the legislature acknowledged the possible role of private parties to construct or maintain streets and highways, ${ }^{122}$ the legislature also recognized the possible role of a third-party contractor to provide equipment and installation of red-light cameras, which include technological software and specialized technical training that would not otherwise be readily available to a local entity. ${ }^{123}$ This legislative recognition of the need for third-party equipment and installation is contained within section 316.008, which deals specifically and exclusively with the exercise of local power pursuant to the Traffic Safety Act; section 316.008(b) provides that a county or municipality may "install or, by contract or interlocal agreement, authorize the installation of any such detectors" within its respective jurisdiction. ${ }^{124}$

Notably, while the first sub-section of section 316.008 authorizes the local entity's "use of traffic infraction detectors," the second subsection merely provides local authorities with the means to acquire the detectors and ensure proper installation.

Based on the dual purposes of both the Traffic Safety Act and the Traffic Safety Code, the legislature defers to the discretion of the Department of Transportation, an agency appointed with the task of up-

118 FLA. STAT. \$ 316.008(8) (2011).

119 FLA. STAT. \$ 316.008(8)(a) (2011).

120 In section 316.003, the term "[t]raffic infraction detector," as it appears within Chapter 316, including the Uniform Traffic Code and the Traffic Safety Act, is defined as

[a] vehicle sensor installed to work in conjunction with a traffic control signal and a camera or cameras synchronized to automatically record two or more sequenced photographic or electronic images or streaming video of only the rear of a motor vehicle at the time the vehicle fails to stop behind the stop bar or clearly marked stop line when facing a traffic control signal steady red light.

FLA. STAT. § 316.003(87) (2011).

121 FLA. STAT. \$ 316.008(8)(a) (2011).

122 FLA. STAT. \$ 316.008(1)(b) (2011).

123 FLA. STAT. \$ 316.008(1)(b), (8)(b) (2011).

124 FLA. STAT. § 316.008(8)(a)-(c) (2011).

125 Compare FLA. STAT. $\$ 316.008(a)$, with FLA. STAT. $\$ 316.008(\mathrm{~b})$. 
holding the guidelines of the Code and ensuring statewide uniformity in traffic regulation.

In conjunction with the legislature's intention to confer to local authorities the power to utilize traffic infraction detectors, the Traffic Safety Act's legislative history reflects the legislature's concern with the possibility that local authorities may invoke the Act and, consequently, frustrate the Code's purpose of ensuring statewide uniformity. ${ }^{127}$ Within a staff report providing substantive analysis of traffic control devices that are installed and operated by the state and local governments, the legislature acknowledged that "all public bodies or officials that purchase and install traffic control devices in Florida must ensure that such devices conform to the manual and specifications of the [Department of Transportation].."128

Accordingly, the Code requires the municipality or county to erect appropriate signage to inform drivers approaching an intersection equipped with a traffic infraction detector. ${ }^{129}$ The signage must be in compliance with the requirements of Florida Department of Transportation. ${ }^{130}$ Specifically, this requirement was imposed upon the municipality and/or county according to their role within the meaning of the Act, wherein the local entity could elect to utilize traffic infraction detectors but, in so doing, would also be required to take measures to ensure the uniformity and consistency throughout the state. ${ }^{13}$

Based on the legislative history, the Act cannot be construed as having been intended to include the role of red light camera vendors and/or manufacturers in erecting the appropriate signage.

Although, standing alone, the signage provisions of various agreements between the private contractors and a given county or municipality are not necessarily unlawful, these provisions should be taken within the contexts of the entire contracts. In the aggregate, these contracts ultimately open the door for the municipality to delegate all its responsibilities to one private contractor in one contract,

126 In section 316.003, the term "department," as it appears within Chapter 316, including the Uniform Traffic Code and the Traffic Safety Act, is defined as "[t]he Department of Highway Safety and Motor Vehicles ... Any reference [within this chapter] to Department of Transportation shall be construed as referring to the Department of Transportation ... or the appropriate division thereof." FLA. STAT. § 316.003(8) (2011).

127 See, e.g.,H.R. STAFF ANALYSIS, April 26, 2011, H.R. 149, Reg. Sess. (Fla. 2011).

128 Id.

129 FLA. STAT. § 316.0776(2)(a) (2010) ("If the department, county, or municipality installs a traffic infraction detector at an intersection, the department, county, or municipality shall notify the public that a traffic infraction device may be in use at that intersection .... Such signage used to notify the public must meet the specifications for uniform signals and devices adopted by the Department of Transportation ....").

130 Id.

131 Id. 
ultimately allocating all governmental duties of a legislative scheme that was intended to remain within the authority of the local government - not of a private company.

The procedures for issuance and processing of citations enumerated in the Act provide specific directives addressed to the municipalities and/or counties. ${ }^{132}$ Section 318.0083(1)(a) of the Act allows the department, a county, or a municipality to "authorize a traffic infraction enforcement officer ... to issue a traffic citation" for one's failure to stop at a red light. ${ }^{133}$ This provision reflects the traditional enforcement of traffic infractions by an officer's personal issuance of a citation. ${ }^{134}$

Subsequently, the legislature included the following provision in order to incorporate the newly-implemented automated infraction detectors with the traditional traffic enforcement procedure: notwithstanding the authorization for a traffic enforcement officer to issue a citation, local authorities may authorize "review of information from a traffic infraction detector by an authorized employee or agent of the department, a county, or a municipality before issuance of the traffic citation by the traffic infraction enforcement officer." ${ }^{135}$

Prior to the Act's final enactment, the bills presented to the legislature made a distinction between the traffic-infraction detector and the traffic infraction enforcement officer, wherein the detector is a machine that produces data that is read by a person, namely, the officer, who is authorized to review and/or issue notice violations. ${ }^{136}$ Together, the report of an officer and the data collected by the detectors would be akin to the presence of the officer during the violation. However, the legislature had no reason to believe this was a "tiered" process like the one created by the agreements between the municipalities and the private contractors, although such process has recently been judicially recognized in a few cases."

132 FLA. STAT. \$ 316.0083(1)(a) (2010).

133 Id.

134 See Letter from Charlie Crist, supra note 7.

135 FLA. STAT. § 316.0083(1)(a) (2010).

136 Compare Fla. STAT. $\$ 316.0083$ (2010), with H.R. STAFF AnAlYsis, Apr. 26, 2011, H.R. 149, Reg. Sess. (Fla. 2011); H.R. StAFF ANALYsIS, Apr. 13, 2010, H.R. 325, Reg. Sess. (Fla. 2010); H.R. StafF ANAlysis, Apr.. 19, 2010, H.R. 325, Reg. Sess. (Fla. 2010); and S. Bill ANALYsis \& FiscAl IMPACT StATEMENT, Apr. 14, 2010, S.B. 2166, Reg. Sess. (Fla. 2010).

137 Id. See, e.g., Williams v. Redflex Traffic Sys., Inc., No. 3:06-cv-400, 2008 WL 782540, at *2 (E.D. Tenn. 2008) ("Redflex employees review the images taken from the camera or images demonstrating that a particular motor vehicle ran a red light. If the license tag number is visible, then the Redflex employee provides an image of the violation which demonstrates the violation and clearly shows the license number of the vehicle. Still photos taken from the video showing the violation are sent to the Knoxville Police Department where an officer views the snapshot(s) and sends the citation to the registered owner of the vehicle. Under the Program, the fine can be 
B. Municipality Ordinances Based On Broad Interpretation of the Act

The Traffic Safety Act was intended to enable local authorities to utilize automated traffic infraction detectors as alternative mechanisms for enforcing red-light running violations and promoting traffic safety. $^{138}$ Subsequent to enactment of the enabling legislation, local authorities statewide enacted ordinances in order to adopt the use of red-light camera systems. ${ }^{139}$

Prior to the Act's enactment, the City of Pembroke Pines requested an opinion from the Attorney General as to whether the city could utilize unmanned cameras to record, but not necessarily enforce, red light violations. ${ }^{140}$ The Attorney General opined that, based on sections 316.002 and 316.008 of the Florida Statutes, the City of Pembroke Pines had the authority to enact an ordinance allowing the use of automated infraction detectors in order to monitor red-light violations and record the license plate number of the car violating the traffic signal. ${ }^{141}$

Based on the Attorney General's opinion, even if the City had the power to monitor traffic by utilizing traffic infraction detectors, a court must still abide by judicial precedent in order to ascertain the scope of authority delegated in an enabling act. ${ }^{142}$ Therefore, the Attorney General acknowledged the role of the court upon judicial review: "It is a rule of statutory construction that an express power duly conferred may include the implied authority to use the means necessary to make the express power effective, although such implied authority may not warrant the exercise of a substantive power not conferred."

In order to uphold uniformity through the State Uniform Traffic Code, the legislature attempted to define the scope of permissible actions in the context of local authorities utilizing automated trafficinfraction detectors. ${ }^{144}$ Section 316.0776 of the Florida Statutes pro-

paid by mail to Redflex."); Agomo v. Fenty, 916 A.2d 181, 189 (D.C. 2007) ("Where an image is recorded by system cameras - and unless the image is indecipherable (e.g., no clear image of the license plate) or patently unusable (e.g., in speeding photos, more than one vehicle in the 'detection area') - a 'draft' [ticket] is prepared by ACS personnel for review by an MPD [Metropolitan Police Department] officer.").

138 See FLA. STAT. $\$ 316.0083$ (2012).

139 See infra note 148.

140 See Letter from Charlie Crist, supra note 7.

141 Id.

142 Id.

143 Id. (citing Molwin Inv. Co. v. Turner, 167 So. 33 (Fla. 1936)).

144 See, e.g., FLA. STAT. $\$ 316.0776$ (2010). 
vides specific requirements if "the department, county, or municipality" exercises the authority conferred to it by the Act.

The language contained within this provision of the Uniform Code further reflects the legislative intent to require accountability by the local entity implementing the use of red-light cameras: "if the department, county, or municipality installs a traffic infraction detector at an intersection, the department, county, or municipality shall notify the public that a traffic device may be in use." ${ }^{146}$ Furthermore, if the local entity "begins a traffic infraction detector program in a county or municipality that has never conducted such a program, the respective department, county, or municipality shall also make a public announcement and conduct a public awareness campaign of the proposed use of traffic infraction detectors." ${ }^{, 147}$

However, the purpose of uniformity in statewide traffic enforcement is substantially aggravated by the Act's broadly-defined adoption of automated traffic infraction detectors. Based on the Act's vaguely permissive language, these "traffic safety" ordinances reflect the broadly-construed scope of implementing automated traffic detectors and enforcing photo-captured violations thereafter. ${ }^{148}$ Furthermore, the markedly varied degree and extent of the traffic safety ordinances reflects the inconsistency of the municipalities' interpretation of the Act. ${ }^{14}$

The Act enables "local departments, municipalities, and agencies" to implement automated traffic infraction detectors. ${ }^{150}$ Some of the subsequent ordinances enacted by these "local departments, municipalities, and agencies" delegate the task of implementing the automated traffic systems to a specific entity or individual within its jurisdiction. $^{151}$ However, other ordinances expressly adopt language similar

145 See, e.g., FLA. STAT. $\$ 316.0776(2)$ (a) (2010).

146 Id.

147 See, e.g., FLA. STAT. \$ 316.0776(2)(b) (2010).

148 Compare Miami Gardens, Fla., Code of Ordinances $\S 24-21$ (2011), with Homestead, Fla., CODE OF ORdinances § 18-6 (2012); Sunrise, Fla., Code OF ORDinANCES § 14-74 (2012); AVENTURA, FlA., CODE OF ORDinANCES $§ 48-26$ (2012), and COLlier CNTY., Fla., CODE OF ORdinANCES § 78-54 (2012).

149 Id.

150 See supra note 145.

151 Collier CNTY., Fla., CODE OF ORdinAnCES § 78-54 (2012) ("The County Manager is authorized to implement the provisions and requirements of the Mark Wandall Traffic Safety Act ... within this jurisdiction in coordination with the Sheriff."); TALLAHASSEE, FLA., CODE OF ORDINANCES $\S 20-50$ (a) (2012) ("The city manager or his/her designee is authorized to implement a system utilizing traffic infraction detectors pursuant to F.S. $\S 316.0083$.") (emphasis added); MiAmi-DADE CNTY., FlA., CODE OF ORDINANCES § 30-422(3) (2012) ("The Mayor or designee is authorized to implement the provisions and requirements of the Act ....") (emphasis added); GAINESVILlE, FlA., CODE OF ORDINANCES § 5-12 (2012) ("The city manager, or his/her designee, is authorized to implement a system utilizing traffic infraction detectors pursuant to the 
to the Act, reflecting a broad delegation to the entire local entity, rather than the specific entity that will, in actuality, undertake the task delegated. $^{152}$

Although a rarity by comparison to the statewide majority, a few ordinances expressly acknowledge the possibility for contracts with private companies as a source of utilizing the municipality's authority to use automated traffic detectors. ${ }^{153}$ The City of Margate's ordinance is arguably the most transparent and narrowly-tailored acknowledgment of third-party involvement: "The city manager is authorized to implement the provisions and requirements of [the Act], including but not limited to, proposing the use of outside vendors to city commissioners to assist the city with implementing the installation and logistics of the use of traffic infraction detectors." ${ }^{154}$ Albeit a much weaker acknowledgement, Manatee County's ordinance recognizes the use of a third party authorized to collect the penalties imposed by the ordinance.

Notwithstanding these anomalous examples, the majority of ordinances remain silent regarding the use of private, third-party companies to implement and operate automated traffic detectors. The majority of municipalities enacting these ordinances, however, currently contract with a few private companies, usually located outside the state of Florida, to install, monitor, and operate automated systems.

Nonetheless, even when the resolutions for such contracts were submitted for approval, city authorities often eluded any explicit discussion over the contractual relationship created between the city and the private company. ${ }^{156}$ Strikingly, even in the instance of public dis-

provisions and requirements of F.S. § 316.0083 ....”) (emphasis added); EsCAMBIA CNTY., FLA., CODE OF ORDINANCES $\S 94-183$ (b) (2012) ("Escambia County, through the county administrator, or his or her designee, is authorized to install and utilize traffic infraction detectors ...") (emphasis added).

152 Aventura, Fla., Code of Ordinances $\S 48-41$ (2012); Sunrise, Fla., Code of ORDINANCES $\S 14-74$ (2012) ("The city may utilize traffic infraction detectors as an ancillary deterrent to traffic control signal violations ...."); HOMESTEAD, FLA., CODE OF ORDINANCES § 18-21 (2012) ("When the city installs a traffic infraction detector at an intersection, it shall erect signage at the intersection ...."); West PALM BEACH, Fla., CODE OF ORdinANCES $\S 86-200$ (2012) ("The city exercises its option under F.S. $\S 316.008$, to use traffic infraction detectors within its jurisdiction ....").

153 See discussion infra Part III.B.

154 Margate, Fla., Code OF ORdinAnCES § 17-73.1 (2011).

155 MANATEE CNTY, FlA., CODE OF ORdinANCES § 2-22-74 (2011) ("[T]he county administrator may either through staff or third party vendors employ such collection efforts ....") (emphasis added).

156 See, e.g., Reg. Meeting Minutes R-10-0387 at 69-70 Dep’t Of Capital Improvements Program, City of Miami City Comm'n (Sept. 16, 2010), available at http://egov.ci.miami.fl.us/ meetings/2010/9/2093_M_City_Commission_10-09-16_Verbatim_Minutes_(Long).pdf. ("The critical step in the process is that once a potential violation is identified, the information is electronically 
sent over such contracts, local authorities dodged the issue of contracting away its authority to a private company, dismissing the public concern without even acknowledging the potentially damaging implications. $^{157}$

\section{Contracts Between Municipalities and Companies Providing Red-Light Cameras}

Based on local entities' broad interpretation of the Traffic Safety Act and subsequently-enacted ordinances, the majority of legislation pertaining to the automated traffic-infraction detectors remains silent on the employment of a private, third-party company located outside the state. However, most municipalities expressly confer to private companies the authority to implement and utilize the automated systems-the authority that the legislature expressly conferred to the local entities themselves.

In February 2011, the City of Deland entered an agreement with Sensys America, Inc., an agreement that strayed from the predominance of ATS in the statewide trend towards privatization of red-lightcamera programs. $^{158}$ Nevertheless, similar to the majority of agreements between private contractors and the local governmental en-

forwarded to the City where a traffic infraction enforcement officer views the footage and gives that final authorization for - of a violation to be issued.").

157 In a city commission meeting on September 16, 2010, a resolution was proposed to approve an agreement between the City of Miami and American Traffic Solutions, wherein the company would "furnish, install, operate and maintain a traffic infraction detector program." See $i d$. When the city commission opened the floor for public discussion, a Miami resident expressed his concern, albeit somewhat inarticulately, about the contract resolution: "But listen, going to be a problem because ATS is a private entity. It's not a government function. It's not government." Subsequently, the speaker began a somewhat rambling discussion, citing the common law, the Constitution, and the American Civil Liberties Union. At some point, a commissioner interrupted the man's oration and dismissively responded, "Thank you." An exchange of unintelligible words ensued between the two individuals, wherein the commissioner demanded that the man "quote ... the amendment for equal protection," and the man relentlessly emphasized, "ATS is not a government agency." Ultimately, since the man could not explicitly cite legal doctrine, the commissioner dismissed the man altogether, without any discussion of his underlying, and arguably meritorious, argument against the role of ATS in the operation of the traffic infraction program. Id.

158 Initially, the City of Deland selected LaserCraft, Inc. for the implementation of the Red Light Program, but before any installations, a class action suit was filed in the State of Florida challenging the legality of the program. When the litigation was settled and the Act was finally enacted throughout Florida, LaserCraft was purchased by ATS. However, since ATS was not the vendor initially selected for the contract, the city once again issued a request for bid proposal. This time around, the city selected Sensys America, Inc. See Request for Comm'n Action from William Ridgway, Finance Dep't Head, to City Mgr., City of Deland, Fla., (Feb. 7, 2011) (on file with author). 
tity, ${ }^{159}$ the agreement included a provision in which Sensys was required to perform an "initial review" in preparing and processing the citation recorded by the traffic infraction detector.

The provision, entitled "Citation Preparation and Processing Services," defined the company's role subsequent to the detection of a traffic infraction by the company's equipment: "Sensys shall perform initial review of all data generated at the roadside, process and format violations utilizing a computerized traffic citation program . . . and transfer the citations to the Police Department's computer for review and decision on whether or not to issue a citation. ${ }^{161}$

This additional tier in the processing of a citation once a traffic infraction detector has already recorded the data is precisely where the legal issue lies. The legislature may have contemplated the implementation of red-light-camera programs, which would entail utilizing a traffic infraction detector supplied by a private company. However, beyond the actual hardware of the equipment, the legislature never addressed or even acknowledged the role of a private company in initially reviewing the data prior to the statutory review by a traffic infraction enforcement officer. ${ }^{162}$

Nonetheless, even if the initial review could be performed by a person other than a duly sworn officer, such as a "specifically-trained technician," ${ }^{163}$ the legislative history addressed this initial review without any indication that this tier could be performed by any person outside the state of Florida: "Traffic infraction enforcement officers ... must be physically located in the county or adjacent county in which infractions he or she enforces occur, or in the jurisdiction of the circuit court where the violation occurred ....",164

Although such a restrictive mandate ultimately died on the Senate floor prior to enactment of the Act, this provision indicates the

159 "Infraction Processing ... The Vendor shall make the initial determination that the image meets the requirements of the Ordinance and this Agreement, and is otherwise sufficient to enable the City to meets [sic] its burden of demonstrating a violation of the Ordinance. If the Vendor determines that the standards are not met, the image shall not be processed any further." Agreement Between the City of Aventura and Am. Traffic Solutions for Traffic Safety Camera Program (February 8, 2008) (on file with author) [hereinafter Agreement Between the City of Aventura and Am. Traffic Solutions].

160 See Request for Comm'n Action from William Ridgway, Finance Dep't Head, to City Mgr., City of Deland, Fla. (Feb. 7, 2011) (on file with author).

161 Id. (emphasis added).

162 Compare Fla. STAT. § 316.0083 (2010), with H.R. STAFF ANALYsis, April 26, 2011, H.R. 149, Reg. Sess. (Fla. 2011); H.R. StAFF AnAlysis, April 13, 2010, H.R. 325, Reg. Sess. (Fla. 2010); H.R. STAFF ANALYSIS, March 9, 2010, H.R. 325, Reg. Sess. (Fla. 2010), and S. BILl ANALYSIS \&FisCAL IMPACT STATEMENT, April 21, 2010, S. 2166, Reg. Sess. (Fla. 2010).

163 See, e.g., H.R. STAFF ANALYsis, April 13, 2010, H.R. 325, Reg. Sess. (Fla. 2010).

164 S. Bill AnAlysis \& Fiscal ImpaCt StATEMENT, Apr. 21, 2010, S.B. 2166, Reg. Sess. (Fla. 2010). 
locality was intended for the processing and issuance of citations for violations recorded by the traffic infraction detectors. ${ }^{165}$ Furthermore, based on this provision within the context of its legislative history, the legislature may have intended to hone in on the locality, but neither acknowledged nor addressed the notion of an initial review by anyone other than an officer or technician within the state.

In theory, the legislature opted not to restrict the municipality by requiring a duly sworn officer within the jurisdiction where the infraction took place, yet did not necessarily intend for this silence to be construed broadly as to allow a third-party, private contractor, located outside the state, to act as a "filter" for the initial review of data recorded using traffic infraction detectors.

\section{DOCTRINAL LIMITATIONS FOR CONTRACTS BETWEEN LOCAL GOVERNMENT AND PRIVATE ENTITIES}

In light of the legislative history leading up to the enactment of the Traffic Safety Act and the subsequent ordinances enacted locally therefrom, the question is whether the current policies of state and local authorities, and their ongoing contractual relationships with the private companies providing "traffic infraction systems or programs," including not only the equipment but also the operation, maintenance, review, and issuance of citations, comports with the laws limiting scope of municipality power in order to safeguard against unfair business practice and covert collusion.

\section{A. Ultra Vires Doctrine}

As a means of providing accountability for municipalities' exercise of authority, courts have invoked the ultra vires doctrine, the "long established principle that a municipality cannot contract away the exercise of its police powers." pality may not enter into a contract that ultimately transfers to a private entity or individual the municipality's executive authority.

In Morgran Co., Inc. v. Orange Cnty., Morgran entered into an agreement with Orange County, executed by a county chairman, "on behalf of the Board of County Commissioners." ${ }^{168}$ Based on this agreement, the county was obligated to "support and expeditiously

165 Id.

166 Morgran Co., Inc. v. Orange Cnty., 818 So. 2d 640, 642 (Fla. 5th DCA 2002) (citing Harnett v. Austin, 93 So. 2d 86, 89 (Fla. 1956); Chung v. Sarasota Cnty., 686 So. 2d 1358 (Fla. 2d DCA 1996)).

167 Id.

168 Id. at 643. 
process" Morgran's re-zoning application in exchange for a 50-acre donation to the county for use as a park once the County fulfilled its promise to "expeditiously support" Morgran's application.

After Morgran submitted the re-zoning application, the county rejected the re-zoning requests set forth therein and ultimately denied Morgran's application. ${ }^{170}$ Soon thereafter, Morgran filed suit against the county for a breach of its agreement to support his application in exchange for his donation of land for use as county property.

Morgran's argument attempted to distinguish between "an obligation to support the request for rezoning and an obligation to approve the request." ${ }^{172}$ In an attempt to defend the contract between the county and the private contractor, Morgran argued that both contracting parties, well aware of the laws governing contract zoning, constructed "carefully worded, highly negotiated contract language that '[did] not purport, either impliedly or expressly, to restrict or any way interfere with, the exercise of the Board of Commissioner's police power as the final zoning authority in the County.", "173

The court rejected Morgran's argument, statinding: "[t]his argument, we fear, draws too fine a distinction.... In Chung, in rejecting a similar argument, the court noted that any hearings regarding the issue of rezoning would 'be a pro forma exercise since the County has already obligated itself to a decision.","174 Accordingly, the court found that the agreement between Morgran and the County was "unambiguously void as a matter of law, since ... [it] requires the County to contract away its police powers." ${ }^{, 175}$

In P.C.B. P'ship v. City of Largo, the city entered into an agreement that purportedly restricted the city's authority in deciding whether to a build a road, install a traffic device, and/or permit the construction of a parking lot and storm drainage. ${ }^{176}$ In order to decide whether the agreement between the city and the private entity was a valid contract, the court found that "[t]he City [did] ... not have the authority to enter into such a contract, which effectively contract[ed] away the exercise of its police powers.",

169 Id. at 641.

170 Id. at 642 .

171 Id.

172 Id. at 643.

173 Id.

174 Id. (citing Chung v. Sarasota Cnty., 686 So. 2d 1358, 1360 (Fla. 2d DCA 1996)).

175 Id. at 642 .

176 P.C.B. P'ship v. City of Largo, 549 So. 2d 738 (Fla. 2d DCA 1989).

177 Id. at 741 (citing Harnett v. Austin, 93 So. 2d 86 (Fla. 1956); City of Belleview v. Belleview Fire Fighters, Inc., 367 So. 2d 1086 (Fla. 1st DCA 1979); City of Safety Harbor v. City of Clearwater, 330 So. 2 d 840 (Fla. 2d DCA 1976)). 
In so finding, the court invoked the ultra vires doctrine, which essentially invalidates a contract where a municipality does not have the power to delegate its authority to a third-party, private contractor. ${ }^{17}$ Basically, the rationale underlying the ultra vires doctrine is that if an ordinance delegates to municipal officials an arbitrary discretion, without providing definitive rules to guide the exercise of this delegated authority, the ordinance cannot be enforced. ${ }^{17}$

In County of Volusia v. City of Deltona, the court similarly invoked the ultra vires doctrine in order to invalidate an agreement between the city and a private agency, where the city's ordinance did not contain "objective guidelines and standards for its enforcement ... nor [could] such be reasonably inferred from the language of the ordinance." The court ruled that "an agreement effectively contracting away a city's exercise of its police power is unenforceable."

The invalidating proposition underlying the ultra vires doctrine is foundationally based on the general principle that " $[\mathrm{u}]$ nrestricted discretion in the application of a law without appropriate guidelines and determining its meaning may not be delegated by the City Council to an agency or to one person." ${ }^{, 182}$

\section{B. Contracts Based on Ordinances}

Although a contract itself may be invalidated based on its unlawful delegation of unbridled discretion to a third-party entity, a substantially more complex legal issue arises where the contract is based on a municipal ordinance. Accordingly, where a municipality enters into an agreement based on a municipal ordinance, the issue becomes whether the ordinance itself also violates the legislative delegation of authority conferred through an enabling statute.

Generally, courts exercise a substantial degree of legislative deference, wherein an ordinance is presumptively within the authority and discretion of its enacting municipality. ${ }^{183}$ The general principle is that a municipal ordinance is inferior to the statute and, thus, cannot

178 Id. at 741 (citing Harnett v. Austin, 93 So. 2d 86 (Fla. 1956) ("While we have not found a reported case in Florida regarding an ultra vires contract similar to the one in this case, a North Carolina case is directly on point....[T]he contract, which purported to restrict the discretion of the governing body of the municipality to determine whether the street should be opened for the public benefit, was ultra vires and of no legal effect.")).

179 Amara v. Town of Daytona Beach Shores, 181 So. 2d 722, 724 (Fla. 1st DCA 1966) (citing Permenter v. Younan, 31 So. 2d 387 (Fla. 1947)).

180925 So. 2d 340, 346 (Fla. 5th DCA 2006).

181 Id. at 345 (citing P.C.B. P'ship, 549 So. $2 \mathrm{~d}$ at 741-42).

182 City of Miami Beach v. Fleetwood Hotel, Inc., 261 So. 2d 801, 806 (Fla. 1972) (citing Stewart v. Stone, 130 So. 2d 577 (Fla. 1961)); Amara, 181 So. 2d at 722.

183 City of Kissimmee v. Fla. Retail Fed'n, 915 So. 2d 205, 209 (Fla. 5th DCA 2005). 
conflict with any controlling provision of that statute. ${ }^{184}$ However, upon judicial review, a court should "indulge every reasonable presumption in favor of an ordinance's constitutionality." ${ }^{185}$

Therefore, in order for an ordinance to be legislatively preempted, the state law and the local ordinance must "contradict each other in the sense that both . . cannot co-exist., ${ }^{186}$ In order to ascertain the validity of the ordinance, the question before the court is: "does compliance with the ordinance violate the state law, or make compliance with state law impossible? It is not a conflict if the ordinance is more stringent than the statute. ${ }^{1,17}$

However, where the issue before the court is based on an ordinance in furtherance of the municipality's police power to promote traffic safety, the legislature explicitly defined the interrelationship between the requirements of the Uniform Traffic Code and the exercise of police power by local authorities: the Code's purpose of promoting statewide uniformity in traffic regulation cannot prevent local authorities from "[r]egulating or prohibiting stopping, standing, or parking. ... Restricting the use of streets ... [or] [r] egulating, restricting, or monitoring traffic by security devices or personnel ... whether by public or private parties," applying to all streets and highways under the municipality's jurisdiction and "within the reasonable exercise of the police power.'

Nonetheless, courts have recognized that modernized government includes the increased use of technological advancement and, accordingly, the need for flexible, loosely drawn standards in regulating legislative enactments under the state's police power. ${ }^{189}$ This recognition of the need for flexible rules so as not to restrict adapting to changing circumstances has been a longstanding proposition, especially in the context of traffic safety: "public streets have never been used by any vehicles that are as dangerous to the public as the automobile, and the power inherent in every municipality to protect life and insure public safety will support all reasonable ordinances, rules and regulations adopted by the proper authority for such purpose."

In recognizing the need for legislation to adapt to technological advancements and modernizations of governmental functions, a court will nevertheless remain steadfast in the notion that, when a statute's

184 Phantom of Clearwater, Inc. v. Pinellas Cnty., 894 So. 2d 1011, 1020 (Fla. 2d DCA 2005).

185 Kissimmee, 915 So. 2 d at 209.

186 F.Y.I. Adventures, Inc. v. City of Ocala, 698 So. 2d 583, 584 (Fla. 5th DCA 1997).

187 Id.

188 FLA. STAT. $\S \$ 316.008(1),(1)(a),(1)(\mathrm{g}),(1)(w)(2008)$.

189 City of Miami Beach v. Fleetwood Hotel, Inc., 261 So. 2d 801, 806 (Fla. 1972).

190 Taylor v. Roberts, 94 So. 874, 876 (Fla. 1922). 
delegation of power does not also provide adequate safeguards against "unfairness or favoritism," and when an available safeguard could have easily been provided, the legislation cannot be upheld. ${ }^{19}$ The Florida Supreme Court explained, "[i]n other words, the legislative exercise of the police power should be so clearly defined, so limited in scope, that nothing is left to the unbridled discretion or whim of the administrative agency charged with the responsibility of enforcing the act." 192

Nonetheless, even if the ordinance could be classified as an exercise of local authority to promote health, welfare, safety and/or morality, "it is still necessary that the exactions be fixed in the ordinance with such certainty that the granting and denial ... could not be left to the whim of a private [entity] . . or the administrative agency." ${ }^{193}$ The general proposition underlying the requirement that ordinances be clearly and narrowly drawn is that a municipality cannot delegate its function to legislate - that is, to exercise discretion as to the content of the law. Local authorities may make a law and incorporate therein a condition precedent upon which execution may depend, but it cannot be made to depend on the unbridled discretion of a single individual.

In order to prescribe the permissible scope of an ordinance, courts have compared three interrelated factors: 1) the enacting legislation; 2) the authority conferred to the local entity; and 3) the effect of the local entity's exercise of this authority through an ordinance. ${ }^{195}$

Based on this three-prong comparison, a valid ordinance "must prescribe definite rules and conditions which ... shall [be met] and may not leave the determination ... to the undirected and uncontrolled discretion of even the ... [local] authority."196 Conversely, where an ordinance does not set forth any criteria for making determinations other than simply identifying a general prerequisite, the burden of determining who falls within the ordinance "involve[s] legal questions too intricate to impose as a condition precedent" on a thirdparty entity. 1969))

191 Fleetwood Hotel, 261 So. 2d at 806 (quoting Dickinson v. State, 227 So. 2d 36, 37 (Fla.

192 Id

193 Amara v. Town of Daytona Beach Shores, 181 So. 2d 722, 725 (Fla. 1st DCA 1966).

194 Id. (citing State ex. rel. Taylor v. City of Tallahassee, 177 So. 719, 721 (1937)).

195 Id.

196 Amara, 181 So. 2d at 724 (citing State ex. rel. Ware v. City of Miami, 107 So. 2d 387 (Fla. 3d DCA 1958)).

197 Id. 


\section{V.ANALYSIS}

\section{A. Problematic Operation Of Contracts Between Municipalities And Private Companies}

In a practical and most basic sense, the vast majority of contracts between municipalities and private companies for the installing, furnishing, maintaining, and operating of automated traffic infraction detectors necessarily involves the following sequence of events, commonly referred to as the "traffic-infraction-detector program":

1) Scott's car travels through an intersection after the light has turned red;

2) If his car exceeds a specific speed at a specific time after the light turned red, Scott's car will trigger two sensors, one at the moment his car crosses the line into the intersection, and one at some point further in the intersection; ${ }^{199}$

3) These sensors will instantaneously emit a signal to cameras perched up on poles and situated in such a way that a picture and/or video can capture the entire intersection and, at the same time, capture Scott's car passing through the intersection and his license plate number; ${ }^{200}$

4) These images are then transmitted online to company technicians, usually located outside the state, who initially review the images of Scott's car; ${ }^{201}$

5) Upon review, if the technician concludes that Scott's car did pass through the intersection after the traffic signal turned red, the technician will access an online database provided by Florida's Department of Motor Vehicles, enter in the license plate number, and record Scott's information, including his mailing address, for subsequent issuance of the citation; ${ }^{202}$

6) Once the technician has input Scott's information into an electronic citation template prepared by the company, the citation, includ-

198 See, e.g., City of Miami, Am. Traffic Solutions Contract, supra note 8; City of Ocoee, Am. Traffic Solutions Contractsupra note 40; City of Ft. Lauderdale, Am. Traffic Solutions Contract, supra note 40.

199 See generally U.S. DEP'T TRANSP., OPERATIONAL GUIDELINES, supra note 4.

200 Id.

201 See generally, Memorandum from Lisa R. Rhea, supra note 84; Memorandum from Alex Rey, supra note 84; Memorandum from Louis Moore, supra note 8; Memorandum from Leonard G. Rubin, supra note 84; City of Miami, Am. Traffic Solutions Contract, supra note 8; Orange Cnty., Pilot Project Report of Nov. 2008, supra note 8.

202 See, e.g., Agreement Between the City of Aventura and Am. Traffic Solutions, supra note 159. 
ing images of Scott's car, will then be transmitted to the State for approval by a law enforcement officer; ${ }^{203}$

7) Upon approval, the law enforcement officer's electronic signature will be superimposed on the electronic citation template, ${ }^{204}$

8) The company or the officer will print and mail the citation; and finally,

9) Within a few days, Scott will be issued his "notice of a violation."

In terms of logistics for the automated system's process, the company provides the following services based on its contract with a municipality: furnishing the equipment; installing the device — which, in some cases, includes the company receiving an easement for placing camera posts on private property - at or near the intersection; conducting training programs for law enforcement and city employees using the company's software, and for judicial officers specially trained for appeal purposes to testify in favor of the company's system; maintaining the camera by providing periodic audits; providing and ensuring the security of the electronic database software transmitting information from the camera to the company and law enforcement; monitoring and initially reviewing images to identify an actual violation; accessing the Department of Motor Vehicle database to identify owners' information; transmitting and providing the citation template for law enforcement review; and ultimately, issuing citations and/or collecting fines therefrom. ${ }^{20}$

By contrast, the municipality's contractual obligations with the company require the municipality to take the following actions: provide the company access to traffic signals, including access to the devices' timing and synchronization; designate specific city employees to aid the company's performance of the automated systems, including the company's mandatory training programs for law enforcement and judicial officers; facilitate the process for acquiring an easement of

203 See, e.g., Williams v. Redflex Traffic Sys., Inc., No. 3:06-cv-400, 2008 WL 782540, at *2 (E.D. Tenn. 2008) ("Redflex employees review the images taken from the camera or images demonstrating that a particular motor vehicle ran a red light. If the license tag number is visible, then the Redflex employee provides an image of the violation which demonstrates the violation and clearly shows the license number of the vehicle. Still photos taken from the video showing the violation are sent to the Knoxville Police Department where an officer views the snapshot(s) and sends the citation to the registered owner of the vehicle. Under the Program, the fine can be paid by mail to Redflex."); Agomo v. Fenty, 916 A.2d 181, 189 (D.C. 2007) ("Where an image is recorded by system cameras-and unless the image is indecipherable (e.g. no clear image of the license plate) or patently unusable (e.g. in speeding photos, more than one vehicle in the 'detection area') - a 'draft' [ticket] is prepared by ACS personnel for review by an MPD [Metropolitan Police Department] officer.”).

204 See sources cited supra note 203.

205 See sources cited supra note 203. 
private property for the company's use; enable the company's access to protected driver information; conduct periodic audits of the company's system - so long as the company is given prior notice of the audit; and any other collateral resources necessary for the company's operation of the system. ${ }^{206}$

In most instances, the contracts between local authorities and private companies providing such services expressly delegate almost entirely the scope of the municipalities' police powers. Interestingly, most of these contracts include the transfer of obligations to the private companies through provisions containing language mirroring, almost identically, to the statutory language relating to the municipalities' exercise of permissible police power.

Arguably, such agreements between a municipality and a private company essentially contract away the municipality's police powers in the context of traffic regulation and enforcement. Not only does the company obtain access to public resources that would normally be provided to the municipality and its exercise of traffic enforcement, but the company also obtains the authority to train city employees to adapt to the company's procedures for enforcement.

Nevertheless, the most significant indication of the municipality contracting away its police powers is the company's procedure for initially reviewing images captured by its system prior to review by law enforcement and the subsequent transmission of only those images that the company employee deemed as proof of the violation. Not only is the company employee usually working outside the state and not a sworn law enforcement officer, but he is also exercising his own personal discretion in whether the images captured should be transmitted to law enforcement for approval. Accordingly, the initial review conducted by company employees is the sole determining factor in whether a citation will be issued, for even if law enforcement retains the right to review the images, such review is subsequent to the company employee's initial determination that a violation occurred.

Ultimately, the determination of whether a violation has occurred and a subsequent citation should be issued is left to the discretion of a private, non-state actor, who, in most cases, has never even set foot or tire - on the state roads he monitors, and has never been trained on the law he enforces. 159.

206 See, e.g., Agreement Between the City of Aventura and Am. Traffic Solutions, supra note

207 See, e.g., Memorandum from Louis Moore, supra note 8; City of Miami, Am. Traffic Solutions Contract, supra note 8; Orange Cnty., Pilot Project Report of Nov. 2008, supra note 8. 


\section{B. Potential Challenges To Ordinances Utilizing Automated Traffic Systems}

Because the majority of such ordinances are silent as to the role of a private company in terms of the post-enactment ordinances, the potential challenges of these ordinances seem highly unlikely to carry the day. However, in at least three instances, the municipalities' ordinances may raise some questions of legality. ${ }^{208}$

\section{City Employee's Sole Discretion To Appoint "Designee"}

The most prevalent form of potentially invalid ordinances arises when the municipality names a specific city employee to implement the systems but also includes an alternative "designee," wherein the named employee has the discretion to delegate his own authority to "his or her designee." contain any degree of specificity or guidelines as to whom the named employee may appoint as "his or her designee.",110

Arguably, because the ordinances do not provide any specific criteria or minimum requirements for an appointed designee, the municipality intended this language to permit for the use of a private, third-party company to act as the "designee." "211 The issue here is not only the broad discretion conferred to an individual city employee to delegate away his own authority to implement the entire automated systems, but also the lack of specificity in terms of permissible designees based on explicit criteria to provide guidance and to limit the city employee's discretion to appoint a designee..$^{212}$ Essentially, as these ordinances stand now, a city employee may choose from a limitless pool of potential designees, regardless of whether these designees are state actors or private agents exercising the municipality's power to implement, operate, and maintain automated traffic systems.

208 See discussion supra. Part V.B(1)-(3).

209 See, e.g., TAllahassee, FlA., CODE OF ORDINANCES $\$ 20-50$ (a) (2012) ("The city manager or his/her designee is authorized to implement a system utilizing traffic infraction detectors pursuant to F.S. § 316.0083.") (emphasis added); MiAmi-DAdE CNTY., FlA., CODE OF ORDINANCES $\S 30-422(3)$ (2012) ("The Mayor or designee is authorized to implement the provisions and requirements of the Act ....") (emphasis added); GAINESVILLE, FlA., CODE OF ORDINANCES § 26-33 (2012) ("The city manager, or his/her designee, is authorized to implement a system utilizing traffic infraction detectors pursuant to provisions and requirements of F.S. $\S$ 316.0083 ... .") (emphasis added); Escambia CNTY., Fla., CODE OF ORDinAnCEs § 94183(b)(2012) ("Escambia County, through the county administrator, or his or her designee, is authorized to install and utilize traffic infraction detectors ....") (emphasis added).

210 See sources cited supra note 209.

211 See sources cited supra note 209.

212 See sources cited supra note 209. 
2. Express Deviations From Standard Practices of Uniform Traffic Code

The second instance of potentially problematic ordinances arises in the rare instances in which the municipality expressly deviates from the standard operations of the Uniform Traffic Code. The City of Dunnellon enacted an ordinance allowing the city to "utilize image capture technologies as a supplemental means of monitoring compliance with laws related to traffic control signals ...., ${ }^{213}$ Although the initial provisions do not reflect any deviation from the common practice of municipalities implementing automated systems, a subsequent provision of the ordinance requires notices of photo-captured violations be "addressed using the city's own special magistrates and not through the uniform traffic citations or county courts." 114

Nonetheless, in a collateral ordinance pertaining to the appropriate signage providing notice of the use of automated traffic systems, the city expressly excuses violations of the Uniform Traffic Code's signage requirement, insofar as the ordinance includes the following provision: "Failure to erect, maintain or create these signs shall not invalidate or impair any enforcement of [the automated traffic detectors]."

Strikingly, the ordinance does not address the specific purpose for an alternative method of issuing citations based on its explicit dismissal of the state's uniform traffic citations. ${ }^{216}$ Such explicit deviations from the common operations of traffic regulation are particularly troublesome because the Code's purpose is to promote statewide uniformity of traffic enforcement and procedures therefrom. The Dunnellon ordinance is particularly anomalous based on its express deviation from the common operation of the Uniform Traffic Code, including the Code's provisions on the issuance of uniform traffic citations and the required signage.

Even more questionable, the ordinance deviates substantially from the traditional practices of judicial proceedings relating to photo-captured violations. Insofar as the operation of the city's own

213 Dunnellon, Fla., Code OF Ordinances, § 65-2 (2010) (emphasis added).

214 Id.

215 Compare FLA. STAT. $\$ 316.0776(2)$ (a) (2010) ("If the department, county, or municipality installs a traffic infraction detector at an intersection, the department, county, or municipality shall notify the public that a traffic infraction device may be in use at that intersection .... Such signage used to notify the public must meet the specifications for uniform signals and devices adopted by the Department of Transportation pursuant to s. 316.0745."), with DUNNELLON, FLA., CODE OF ORDINANCES $\S 65-17$ (2010).

216 See, e.g., DUNnELlOn, FLA., CODE OF ORDinANCES $§ 65-17$.

217 Id. 
"special magistrates," a collateral provision of the city's automated traffic program explicitly renders the "formal rules of evidence" inapplicable. ${ }^{218}$ Alternatively, the ordinance provides a specific standard for special magistrate's discretion in allowing or disallowing specific evidence, wherein "all evidence of a type commonly relied upon by reasonable prudent persons in the conduct of their affairs shall be admissible" and "any part of the evidence may be received in written form." 219

Such a flagrant dismissal of the traditional rules of evidence presents the issue of whether alleged violators captured by automated detectors within Dunnellon's jurisdiction are provided adequate process based on the requirements of the Due Process and Equal Protection Clauses.

In the context of due process, a deviation from formal rules of evidence necessarily entails a deviation from the purposes and goals of such rules, including the appropriate procedure required to protect the individual's right to due process.

In terms of equal protection, because the photo-captured violations issued by Dunnellon's automated system do not require the procedural safeguards of formal rules of evidence, the alleged violators may be similarly situated as alleged violators in other jurisdictions, yet Dunnellon violators may not be similarly treated, at least in terms of the admissibility of evidence to challenge a photo-captured violation.

\section{Ordinances Creating Penalties Beyond Imposition of Monetary Fines}

The third instance of potentially problematic ordinances arises where the local authority sets forth specific penalties for an alleged violator who fails to respond to the issuance of a citation by ignoring the citation altogether and failing to pay the fine imposed for the violation. ${ }^{220}$ The traditional imposition of civil penalties has been upheld in the context of automated traffic systems based on the trend of judicial restraint and legislative deference. ${ }^{221}$ Essentially, the imposition of civil, as opposed to criminal, penalties for photo-captured violations does not require any degree of heightened judicial review within the context of citation proceedings.

218 Id.

219 Dunnellon, Fla., Code of Ordinances $\S 65-11(\mathrm{f})$.

220 See, e.g., SARASOTA CNTY., Fla., CODE OF ORDINANCES $§ 122-205$ (c) (2010).

221 See discussion supra Part II.C (explaining the distinction between civil and criminal penalties, specifically in the context of the required process due for the imposition of such penalties).

222 See discussion supra Part II.C. 
Although the majority of municipalities utilizing automated systems impose a civil penalty and subsequent collections process for failure to pay the citation, the penalty scheme set forth in Sarasota County's ordinance relating to photo-captured infractions imposes a strikingly stringent form of liability: "suspension of county privileges," wherein an alleged violator's failure to pay the civil fine will necessarily lead to the suspension, refusal, and denial of "any rights and privileges that such person may otherwise be entitled to enjoy, receive, or benefit from the County .....223 Specifically, the potentially revocable rights and privileges of the county include "the right to obtain and maintain an occupational license, the right to utilize County facilities, the right to obtain any licenses or permits contemplated in the Code.'

The county's imposition of a particularly stringent penalty scheme raises substantially more complex issues than the "mere civil fine" commonly imposed for photo-captured violations. ${ }^{225}$ Whereas the process due in the context of civil fines is less demanding since the penalty is limited to monetary loss, the county's imposition of its own specific penalties far exceeds the scope of monetary fines - the failure to pay such fines necessarily requires an outright denial of an individual's rights to lawfully pursue his occupation by obtaining an occupational license, to enjoy public facilities, to conduct business, and to travel lawfully by obtaining required licenses and permits. ${ }^{226}$

The penalty scheme set forth in the county ordinance is potentially troublesome in light of the heightened penalties and the requirements of the Due Process and Equal Protection Clauses. ${ }^{27}$ In the context of due process, the possibility for an outright denial of an individual's rights and privileges of the county would necessarily require a heightened standard for citation proceedings because the loss of these rights exceeds beyond the scope of a civil fine. ${ }^{228}$ Furthermore, in the context of equal protection, alleged violators adjudicated under the county's jurisdiction may be similarly situated to those violators in other jurisdictions, yet the substantial restrictions imposed on individuals within the county far exceeds the imposition of civil penalties under jurisdictions outside the county. ${ }^{229}$

223 Sarasota CNTY., Fla., CODE OF ORdinanCES $§ 122-205$ (c) (2010).

224 Id.

225 See discussion supra Part II.C.

226 SARASOTA CNTY., Fla., CODE OF ORdinANCES § 122-205(c)

227 See discussion supra Part II.C

228 SARASOTA CNTY. CODE OF ORDINANCES. § 122-205(c).

229 See discussion supra Part II.C. 


\section{CONCLUSION}

Aside from the three particularly anomalous instances of potentially challengeable ordinances, the statewide implementation of automated traffic detectors pursuant to the Mark Wandall Traffic Safety Act does not, in and of itself, necessarily violate an individual's constitutional rights. Specifically, so long as the state-implemented use of red-light cameras imposes only a civil penalty for violations captured therefrom, the degree of process due is substantially less strict than the imposition of a punitive, criminal penalty. Based on this characterization, the photo-captured infractions are akin to, albeit more expansive than, a citation issued for an expired parking meter.

The implementation of red-light camera equipment itself is not a particularly strong point of contention because local authorities undoubtedly have the authority to regulate traffic regulation and enforcement within their jurisdictions based on their police powers therein. Moreover, the monitoring of such images does not necessarily implicate any infringement on an individual's diminished expectation of privacy in the context of public roadways. Accordingly, the use of such systems to capture violations and issue citations therefrom generally avoids any challenges based on an individual's constitutional rights protecting against self-incrimination and providing the opportunity to confront one's accusers - so long as the penalties for photocaptured violations is explicitly and implicitly characterized as a civil, non-punitive penalty.

However, the widespread public dissent against these automated infraction detectors is not necessarily an uphill battle once the focus of such challenges goes beyond individual constitutional analysis. Specifically, judicial attention must be had for the actual realities of the internal affairs underlying the use of automated traffic systems.

As a general trend, most challenges have focused on legislation, which, on its face, remains silent as to the use of private companies contracted to undertake the functions specifically delegated to local authorities, not to private entities. In this context, challenges to the red-light cameras will remain relatively unsuccessful since both state statute and local ordinances generally comport with the exercise of police powers in the regulation and enforcement of traffic on state highways, roads, and streets.

Nevertheless, the implementation of automated traffic infraction systems and the consequential public disdain stemming therefrom may be ameliorated by a legislative initiative to prohibit the use of

230 See discussion supra Part II.C. 
foreign companies conducting the tasks that lawfully belong within the geographic and legal jurisdictions of local authorities.

Alternatively, the implementation of a statewide program wherein the state legislature retains the right to regulate the use of automated infraction detectors, ideally, under the sole supervision and control of the Department of Transportation would ensure uniformity and limit the opportunity for unfair or deceptive business dealings between municipalities and private companies.

Ultimately, the introduction of innovative and cost-effective means of promoting public health, safety, and welfare is rapidly developing, and although the legal debate surrounding such innovations quickly gains momentum as the technologies become more widespread, the articulation of standards set forth through coherent, consistent, and cohesive jurisprudence develops at a substantially slower pace.

All in all, the use of automated traffic infraction detectors will remain a familiar fixture of state-run thoroughfares. However, if the current trend of local authorities contracting their police powers to private companies outside the state continues, the exercise of unbridled discretion incidental to an outright delegation of local authority will continue to exacerbate the tension created between the use of such innovative technologies and the lack of public acceptance.

Although the legislature is currently debating the repeal of the Traffic Safety Act altogether, this is merely a reflection of legislative frustration with the ever-growing public outcry against the automated systems. Rather than throwing in the towel on automated traffic infraction detectors, legislative attention must be had for the most efficient means of regulating these systems in a uniform and consistent manner while limiting the possibility for privatizing and outsourcing traffic regulation and enforcement beyond state borders. 